\title{
Review: Natural products from Genus Selaginella (Selaginellaceae)
}

\author{
AHMAD DWI SETYAWAN \\ Department of Biology, Faculty of Mathematics and Natural Sciences, Sebelas Maret University, Surakarta 57126. J1. Ir. Sutami 36A Surakarta 57126, \\ Central Java, Indonesia. Tel./fax. +62-271-663375, email: volatileoils@ gmail.com
}

Manuscript received: 28 Augustus 2010. Revision accepted: 4 October 2010.

\begin{abstract}
Setyawan AD. 2011. Natural products from Genus Selaginella (Selaginellaceae). Nusantara Bioscience 3: 44-58. Selaginella is a potent medicinal-stuff, which contains diverse of natural products such as alkaloid, phenolic (flavonoid), and terpenoid. This species is traditionally used to cure several diseases, especially for wound, after childbirth, and menstrual disorder. Biflavonoid, a dimeric form of flavonoids, is the most valuable natural products of Selaginella, which constituted at least 13 compounds, namely amentoflavone, 2',8"-biapigenin, delicaflavone, ginkgetin, heveaflavone, hinokiflavone, isocryptomerin, kayaflavone, ochnaflavone, podocarpusflavone A, robustaflavone, sumaflavone, and taiwaniaflavone. Ecologically, plants use biflavonoid to response environmental condition such as defense against pests, diseases, herbivory, and competitions; while human medically use biflavonoid especially for antioxidant, antiinflammatory, and anti-carcinogenic. Selaginella also contains valuable disaccharide, namely trehalose that has long been known for protecting from desiccation and allows surviving severe environmental stress. The compound has very prospected as molecular stabilizer in the industries based bioresources.
\end{abstract}

Keywords: natural products, biflavonoid, trehalose, Selaginella.

\begin{abstract}
Abstrak. Setyawan AD. 2011. Bahan alam dari Genus Selaginella (Selaginellaceae). Nusantara Bioscience 3: 44-58. Selaginella adalah bahan baku obat yang potensial, yang mengandung beragam metabolit sekunder seperti alkaloid, fenolik (flavonoid), dan terpenoid. Spesies ini secara tradisional digunakan untuk menyembuhkan beberapa penyakit terutama untuk luka, nifas, dan gangguan haid. Biflavonoid, suatu bentuk dimer dari flavonoid, adalah salah satu produk alam yang paling berharga dari Selaginella, yang meliputi sekurang-kurangnya 13 senyawa, yaitu amentoflavone, 2',8"-biapigenin, delicaflavone, ginkgetin, heveaflavone, hinokiflavone, isocryptomerin, kayaflavone, ochnaflavone, podocarpusflavone A, robustaflavone, sumaflavone, dan taiwaniaflavone. Secara ekologis, tumbuhan menggunakan biflavonoid untuk merespon kondisi lingkungan seperti pertahanan terhadap hama, penyakit, herbivora, dan kompetisi, sedangkan manusia menggunakan biflavonoid secara medis terutama untuk antioksidan, anti-inflamasi, dan anti karsinogenik. Selaginella juga mengandung trehalosa suatu disakarida yang telah lama dikenal untuk melindungi dari pengeringan dan memungkinkan bertahan terhadap tekanan lingkungan hidup yang keras. Senyawa ini sangat berpotensi sebagai stabilizer molekul dalam industri berbasis sumberdaya hayati.
\end{abstract}

Kata kunci: produk alami, biflavonoid, trehalosa, Selaginella.

\section{INTRODUCTION}

Medicinal plant is plant containing substance which can be used for the medication or become precursor of drug synthesis (Sofowora 1982). Medicinal plant has been source of human health since ancient time, whereas about $60-75 \%$ of world populations require plant for carrying health (Farnsworth 1994; Joy et al. 1998; Harvey 2000). Plants and microbes are the main source of natural products (Hayashi et al. 1997; Armaka et al. 1999; Lin et al. 1999a,b; Basso et al. 2005), and consistently become main source of the newest drugs (Harvey 2000). The drug development from natural sources are based on the bioassay-guided isolation of natural products, due to the traditional uses of local plants (ethnobotanical and ethnopharmacological applications) (Atta-ur-Rahman and Choudhary 1999).

Traditional medication system by using plant medicines has been developed during thousands of year especially by Chinese (Wu-Hsing) and India (Ayurveda, Unani and
Siddha) (Peter 2004; Ahmad et al. 2006), while the most advanced, widespread and oldest traditional medication system in Nusantara or Malay Archipelago (Malesia) is jamu which developed by Javanese. Jamu contains several recipes compiled by about 30 plant species. Relief at Borobudur temple about making jamu indicates that jamu has been widely recognized since the early $9^{\text {th }}$ century (Jansen 1993). This system has been documented for centuries in many serat and primbon, Javanese literary (Soedibyo 1989, 1990; Sutarjadi 1990); and spread by trading, migration, and expansion of several kingdoms such as Mataram Hindu (Sanjaya), Srivijaya (Saylendra) and Majapahit.

Selaginella Pal. Beauv. (Selaginellaceae Reichb.) has been used as complementary and alternative medicines in several traditional medications. This matter is traditionally used to cure wound, after childbirth, menstrual disorder, skin disease, headache, fever, infection of exhalation channel, infection of urethra, cirrhosis, cancer, rheumatism, bone fracture, etc. Part to be used is entire plant, though 
only referred to leaves or herbs (Setyawan 2009; Setyawan and Darusman 2008). The usage can be conducted single or combination, fresh or dried, direct eaten or boiled (Dalimartha 1999; Wijayakusuma 2004). This plant has sweet taste and gives warm effect on the body (Bensky et al. 2004). The use of Selaginella as medicinal matter occurs in the entire world. The largest usage is conducted by Chinese, especially for $S$. tamariscina, S. doederleinii, S. moellendorffii, S. uncinata, and S. involvens (Lin et al. 1991; Chang et al. 2000; Wang and Wang 2001). Unfortunately, Selaginella is rarely exploited in Nusantara. Traditional jamu of Java use more cultivated spices and rhizomes than wild herbs or grasses.

Plant medicinal properties are contributed by natural products or secondary metabolites, such as phenolic (flavonoid), alkaloid, terpenoid, as well as non-protein amino acid (Smith 1976). Natural products are chemical compounds or substances produced by a living organism and found in nature that usually has a biological activity for use in pharmaceutical drug discovery and drug design (Cutler and Cutler 2000). In this following discourse, the authors studied diversity of natural products from Selaginella, especially biflavonoid and trehalose compounds; and biological activity of Selaginella's biflavonoid in modern medication.

\section{NATURAL PRODUCTS DIVERSITY}

Previous phytochemical studies on the constituents of genus Selaginella leads to the discovery of many compounds, including biflavonoids, the main secondary metabolite of Selaginella (Sun et al. 1997; Silva et al. 1995; Lin et al. 1994; 2000). Biflavonoid has also distributed to Selaginellales, Psilotales, and Gymnosperms (Seigler 1998), several Bryophytes and about 15 families of Angiosperms (DNP 1992). The other compounds are including lignin (White and Towers 1967); lignan (Lin et al. 1994), lignanoside (Lin et al. 1990; Zheng et al. 2004, 2008b), alkaloid (Zheng et al. 2004; Lin et al. 1997), selaginellin (Zhang et al. 2007; Cheng et al. 2008), glycosides (Ma and Takahashi 2002; Zhu et al. 2008), glucosides (Dai et al. 2006; Yuan et al. 2008), Cglycosylflavones (Richardson et al. 1989), etc. Selaginella species of Java contains alkaloid, phenolic (flavonoid, tannin, saponin), and terpenoid (triterpene, steroid) (Chikmawati and Miftahudin. 2008; Chikmawati et al. 2008). Some species of Japan consist of a steroid type namely ecdysteroid (Takemoto et al. 1967; Hikino et al. 1973; Yen et al. 1974). The diversity and content of other compound are relatively lower than biflavonoid, nevertheless, they have also certain bioactivities.

Water extracts of $S$. tamariscina also has several natural products such as ferulic acid, caffeic acid, vanillic acid, syringic acid, umbelliferone (Bi et al. 2004b); tamariscinoside A, tamariscinoside B, adenosine, guanosine, arbutin (Bi et al. 2004a); tamariscinoside C, tyrosine, D-mannitol, and shikimic acid (Zheng et al. 2004). The EtOH extract of the whole herbs of $S$. tamariscina that fractionated by chloroform and ethyl acetate contains selaginellin A and selaginellin B (Cheng et al. 2008). The main constituen of $S$. tamariscina subsequently is amentoflavone, robustaflavone, bilobetin, hinokiflavone, isocryptomerin and an apigenin-diglucoside (Yuan et al. 2008). S. tamariscina has also many sterols that inhibit the growth of human leukemia HL-60 cells indicating anti-cancer property (Gao et al. 2007). The aerial parts of $S$. pulvinata has steroid constituent (Zheng et al. 2007), and several Selaginella has also sterol (Chiu et al. 1988). Steroid compound namely ecdysteroid has been found in Japanese species of S. deliculata, S. doederleinii, S. moellendorffii, $S$. nipponica, $S$. involvens $(=S$. pachystachys), S. stauntoniana (= S. pseudo-involvens), $S$. remotifolia var. japonica, S. tamariscina, and S. uncinata (Takemoto et al. 1967; Hikino et al. 1973; Yen et al. 1974).

Methanolic extract of $S$. lepidophylla contains 3methylene hydroxy-5-methoxy-2,4-dihydroxy tetrahydrofurane, which can a slight inhibitory effect on the uterus contraction (Perez et al. 1994). S. lepidophylla is also reported to contain volatile oils (Andrade-Cetto and Heinrich 2005). The acetone extract of S. sinensis contains selaginellin A, an unusual flavonoid pigment (Zhang et al. 2007). S. sinensis has a glucoside, namely selaginoside (Dai et al. 2006), a sesquilignan, namely sinensiol A (Wang et al. 2007), secolignans, namely styraxlignolide D and neolloydosin (Feng et al. 2009), and (+)-pinoresinol (Umezawa 2003a,b). S. uncinata also has chromone glycosides, namely uncinoside A and uncinoside B (Man and Takahashi 2002), which shows antiviral activities against RSV and PIV-3 (Ma et al. 2003). Ethanol extract of $S$. uncinata also contains flavonoids that possessing a benzoic acid substituent (Zheng et al. 2008a).

$S$. doederleinii contains several phenolic compounds such as (+)-matairesinol, (-)-lirioresinol A, (-)-lirioresinol B, (-)-nortracheloside (Lin et al. 1994), and (-)matairesinol, (+)-syringaresinol, (+)-wikstromol, (+)nortrachelogenin (Umezawa 2003a,b). The (-)-matairesinol has inhibitory activity against cAMP and acts as an insecticide synergist, while (+)-syringaresinol has cytotoxic effect (Harborne et al. 1999). S. doederleinii also contains a glycosidic hordenine (Markham et al. 1992), which increases hypertension (Lin et al. 1991).

$S$. caulescens, $S$. involvens, and $S$. uncinata contain about $0.2 \%$ silicon, higher than the most of other club mosses and true ferns (Ma and Takahashi 2002), which may improve plant tolerant to disease, drought, and metal toxicities (Epstein 1999; Richmond and Sussman 2003; Ma 2004). S. labordei contains 4'-methylether robustaflavone, robustaflavone, eriodictyol and amentoflavone (Tan et al 2009). S. apoda yields substantial amounts of 3-O-methylD-galactose (Popper et al. 2001). S. moellendorfii contains several pyrrolidinoindoline alkaloids (Wang et al. 2009). Other natural products, besides biflavonoid and trehalose, also have several molecular properties that can increase human health and have economical values; and need for further observation.

Natural products of Selaginella can vary depending on climate, location, and soil factors (Setyawan 2009); as well as harvesting and extraction procedure (Nahrstedt and Butterweck 1997); and also plant species or variety, parts to be extracted and age. The different species of Selaginella 
shows different HPLC fingerprint characteristic. The samples of the similar species, collected in different period, different environment or different locations shows certain difference in fingerprints. However, it also generates main fingerprint peaks, which can be used to evaluate and distinguish the different species or infraspecies (Fan et al. 2007).

\section{BIFLAVONOID}

Selaginella species have a large number of bioactive compounds, the most important being biflavonoids (Silva et al. 1995; Lin et al. 1999). Biflavonoids are naturally occurring compounds that are ubiquitous in all vascular plants and have many favorable biological and pharmacological effects (Lee et al. 1996; Baureithel et al. 1997; Lobstein-Guth et al. 1998). One of flavonoid structure that has high medicinal valuable is biflavonoid; a dimeric form of flavonoid which formed by binding of two flavone units or mixture between flavone and flavanone or aurone (Geiger and Quinn 1976; DNP 1992; Ferreira et al. 2006).

Flavonoid (or flavanoid) is widespread plant natural products $(5-10 \%)$; its chemical structure and biological role are very diverse (Macheix et al. 1990). This compound is formed by shikimate and phenylpropanoid pathways (Harborne 1989), with a few alternative biosyntheses (Robards and Antolovich 1997). Flavonoid is derived from phenols having basic structure of phenylbenzopiron (tocopherol) (Middleton et al. 2000); distinguished by 15 carbon skeletons (C6-C3-C6) consisted of one oxygenated ring and two aromatic rings (Figure 1). Substitution of chemical group at flavonoid is generally hydroxylation, methoxylation, methylation, and glycosylation (Harborne 1980). Flavonoid is classified diversely; among them are flavone, flavonone, isoflavone, flavanol, flavanone, anthocyanin, and chalcone (Porter 1994; Ferreira and Bekker 1996; Ferreira et al. 1999a,b). More than 6467 flavonoid compounds have been identified and amount of new discovery is consistently increasing (Harborne and Baxter 1999). This compound is playing important role in determining color, flavor, aroma, and quality of nutritional food (Macheix et al. 1990). Flavonoid is mostly monomeric form, but there is also dimer (biflavonoid), trimer, tetramer, and polymer (Perruchon 2004).

Biflavonoid (or biflavonil, flavandiol) is a dimeric form of flavonoid which formed by bonding of two flavone units or mixture between flavone and flavanone or aurone (DNP 1992; Ferreira et al. 2006). Basic structure of biflavonoid is 2,3-dihydroapigeninil-(I-3',II-3')-apigenin (Figure 1). This compound has interflavanil $\mathrm{C}-\mathrm{C}$ bond between carbon $\mathrm{C}-3^{\prime}$ at each flavone group. There is also some biflavonoid with interflavanil C-O-C bonding (Bennie et al. 2000, 2001, 2002; Ferreira et al. 2006). Locksley (1973) suggest generic term 'biflavanoid' to replace 'biflavonil' which is early used. Term 'biflavanoid' is assumed more accurate than 'biflavonoid' because indicating saturated in nature. Suffix 'oid' indicates homogeneous dimeric type, including biflavanone, biflavone, biflavan, etc. However, term 'biflavonoid' is more regularly used because of articulated easier.

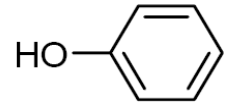

Phenol

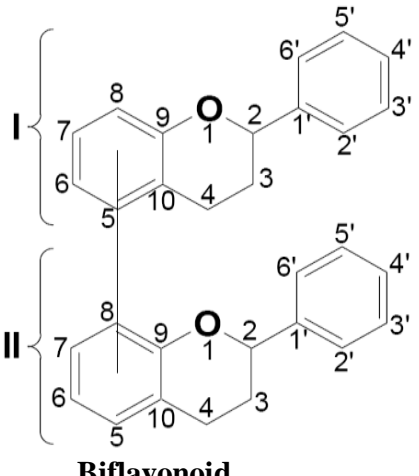

Biflavonoid
Figure 1. Basic structure of phenol, flavanoid, and biflavanoid. Bicyclic ring system is named $\mathrm{A}$ and $\mathrm{C}$ rings, while unicyclic ring is named $\mathrm{B}$ ring. The two units of monomeric biflavonoid is marked by Roman number I and II. Position number at each monomer is started from containing oxygen atom ring, position of C-9 and C-10 indicate unification of them (Rahman et al. 2007).

Biflavonoid is found at fruit, vegetable, and other parts of plant. This compound is originally found by Furukawa in 1929 (Lin et al. 1997) from leaf extract of G. biloba in form of yellow colored compound, later named ginkgetin (I-4', I-7-dimetoxy, II-4', I-5, II-5, II-7-tetrahydroxy I-3', II8 biflavone) (Baker and Simmonds 1940). Nowadays, amount of biflavonoid which isolated and characterized from nature continually increase (Oliveira et al. 2002; Ariyasena et al. 2004; Chen et al. 2005a), but learning to bioactivity is still limited. The most observed biflavonoid is ginkgetin, isoginkgetin, amentoflavone, morelloflavone, robustaflavone, hinokiflavone, and ochnaflavone. Those compounds have similar basic structure, i.e., 5,7,4'trihydroxy flavonoid, but differing at nature and position of flavonoid bond (Rahman et al. 2007).

Biflavonoid has several namenclaturing systems, such as Locksley, IUPAC, and vernacular name. The first of two systems is the most systematic, but the most used is vernacular name. Locksley (1973) standardize nomenclature and position number of biflavonil ring skeleton. Every monomer unit is marked by Roman numerals I and II that indicate bonding between monomer, followed by Arabic numerals indicate that bonding position. The two numeral from two monomer unit compiled dimeric, than paired with hyphen to show bonding position of two monomers. Number of substitution group at monomer unit follow IUPAC system for flavone. In Locksley system, amentoflavone named I-4', II-4', I-5, II-5, I-7, II-7-hexahydroxy I-3', II-8 biflavone, while hinokiflavone which its flavone unit bonded with an oxygen is named by II-4', I-5, II-5, I-7, II-7-pentahydroxy I-4'-O-II-6 biflavone. This system is intuitive, logical, and depicts the chemical structure. In IUPAC, amentoflavone is named by 8-5-(5,7-dihydroxy-4-oxo-4H-chromen-2-il)-2hydroxyphenyl-5,7-dihydroxy- 2-(4-hydroxy-phenyl)- 
chromen-4-on, while hinokiflavone is 6-4-(5,7-dihydroxy4-oxo-4H-chromen-2-il)-phenoxy- 5,7-dihydroxy-2-(4hydroxyphenyl)- chromen-4-on. Basic difference between two systems is a reference of structural skeleton. Locksley use flavanoid structure, while IUPAC uses chromen structure that more complex (Rahman et al. 2007). The above two nomenclature is rarely used because of its complication. Vernacular name that given by each inventor is often used because simpler and easier, though it is not systematic and does not depict chemical structure, such as amentoflavone, hinokiflavone, ginkgetin, etc.

In vivo biosynthesis of flavonoid in nature is relatively mysterious, but there are some approaches by in vitro to explain biosynthesis. According to Rahman et al. (2007) there are nine pathways of biflavonoid synthesis, namely: (i) Ullmann coupling halogenated flavones; (ii) synthesis of biflavones via 1,1'-biphenyls; (iii) metal catalyzed crosscoupling of flavones; (iv) Wessely-Moser rearrangements; (v) phenol oxidative coupling of flavones; (vi) Ullmann condensation with flavone salts; (vii) nucleophilic substitution; (viii) dehydrogenation of biflavanones into biflavones; and (ix) dehydrogenation of biflavone into biflavanone.

In East Asia, biflavonoid is usually produced from leaf of Ginkgo biloba which main constituent is ginkgetin (Krauze-Baranowska and Wiart 2002; Dubber 2005). In sub Sahara-Africa, it is specially produced from seed of Garcinia cola which main constituent is kolaviron (Iwu and Igboko 1982; Iwu 1985, 1999; Iwu et al. 1987, 1990; Braide 1989, 1993; Han et al. 2006; Farombi et al. 2005; Adaramoye and Medeiros 2009). The biflavanones are the most dominant in the most Garcinia species (Waterman and Hussain 1983), pericarp of Javanese mangosteen $(G$. mangoestana) contains amentoflavone and other flavonoids (ADS 2008, data not be shown). In Europe, biflavonoid is commonly produced from herbs of Hypericum perforatum which main constituent is amentoflavone (Berghofer and Holzl 1987, 1989; Nahrstedt and Butterweck 1997; Tolonen 2003; Kraus 2005). Selaginella has potent as source of biflavonoid, which can yield various biflavonoid compounds depending on species. It has cosmopolitan distributed and able to cultivate almost all the words depending on species.

\section{DIVERSITY OF BIFLAVONOID}

Selaginella is one of the potential medicinal plants as a source biflavonoid in Nusantara, where 200 of the 700-750 species from the entire world are found (Setyawan 2008). A total of 13 biflavonoid compounds have been isolated from Selaginella, including amentoflavone (3',8'biapigenin), 2',8"-biapigenin, delicaflavone, ginkgetin, heveaflavone, hinokiflavone, isocryptomerin, kayaflavone, ochnaflavone, podocarpusflavone A, robustaflavone, sumaflavone, and taiwaniaflavone (Figure 2). In Setyawan and Darusman (2008) mentioned that the number is only 12 biflavonoid compounds. Some biflavonoid is easily found at various species of Selaginella, but the other is only found at certain species. Amentoflavone and ginkgetin is biflavonoid compound of the most Selaginella, while sumaflavone is only reported from $S$. tamariscina (Yang et al. 2006; Lee et al. 2008) and delicaflavone is only reported from S. delcatula (Andersen and Markham 2006). At least 11 species of Selaginella have been tested by amentoflavone content (Sun et al. 2006). There is also biflavonoid which is rarely found at Selaginella but it is commonly found at other species. Preliminary study shows that amentoflavone is found in high content (> 20\%) at two of about 35 species of Malesian Selaginella, namely $S$. subalpina and S. involvens (ADS 2008, data not be shown). In Selaginella, taiwaniaflavone is only reported from $S$. tamariscina (Pokharel et al. 2006), while this is also found at another plant such as Taiwania cryptomerioides (Kamil et al. 1981).

Selaginella is generally extracted from whole plant, though it is only conceived as herbs or leaves. Extraction can be conducted by various solvent, i.e. polar, semi-polar and non-polar. For example: boiling in water, extraction by using methanol, ethanol, butanol, ethyl acetate, chloroform, or extraction by using solvent mixtures such as alcoholwater, ethanol-ethyl acetate, and ethanol-chloroform. Methanol and ethanol are the most solvents used for biflavonoid extraction. Solvent types and extraction procedure can influence obtaining chemical structure and bioactivity of extract. Disease which is most treated by Selaginella extract is cancer. Besides, Selaginella extract also has much other usefulness, namely antioxidant, antiinflammatory, antimicrobial (virus, bacterium, fungi, and protozoa), anti UV irradiation, anti-allergy, vasorelaxation, anti-diabetes, blood pressure stability, antihemorrhagic, and antinociceptive. Biflavonoid needs evaluation for its medical and nutritional value (Harborne and Williams 2000). Selaginella contains various biflavonoid with different medical properties (Table 2).

Amentoflavone. Amentoflavone, the most common biflavonoid of Selaginella, has various biological and pharmacological effects, including antioxidant (Mora et al. 1990; Cholbi et al. 1991; Shi et al. 2008), anti cancer (Silva et al. 1995; Lee et al. 1996; Lin et al. 2000; Guruvayoorappan and Kuttan 2007), anti-inflammatory (Gambhir et al. 1987; Baureithel et al. 1997; Gil et al. 1997; Kim et al. 1998; Lin et al. 2000; Woo et al. 2005), antimicrobial (Woo et al. 2005; Jung et al. 2007), antivirus such as influenza (A, B), hepatitis (B), human immunodeficiency virus (HIV-1), herpes (HSV-1, HSV-2), herpes zoster (VZV), measles (Lin et al. 1998, 1999a,b, 2002; Flavin et al. 2001, 2002), and respiratory syncytial virus (RSV) (Lin et al. 1999a,b; Ma et al. 2001), vasorelaxation (Kang et al. 2004), anti-urcerogenic (Gambhir et al. 1987), anti stomachic-ache (Kim et al. 1998), anti depressant (Baureithel et al. 1997), anxiolytic (Cassels et al. 1998, 1999), analgesic (Silva et al. 2001), and anti-angiogenesis agent (Lee et al. 2009c).

2',8'-biapigenin. 2',8"-biapigenin is an anticancer, which inhibit transactivation of iNOS gene and cyclooxigenase-2 (COX-2) through inactivate nuclear factor- $\kappa \mathrm{B}(\mathrm{NF}-\kappa \mathrm{B})$ and prevent translocation of p65 (Chen et al. 2005b; Woo et al. 2006); and anti-inflammatory (Grijalva et al. 2004; Woo et al. 2005 2006; Pokharel et al. 2006). 
<smiles>O=c1cc(-c2ccc(O)c(-c3c(O)cc(O)c4c(=O)cc(-c5ccc(O)cc5)oc34)c2)oc2cc(O)cc(O)c12</smiles>

Amentoflavone (3',8"-biapigenin)

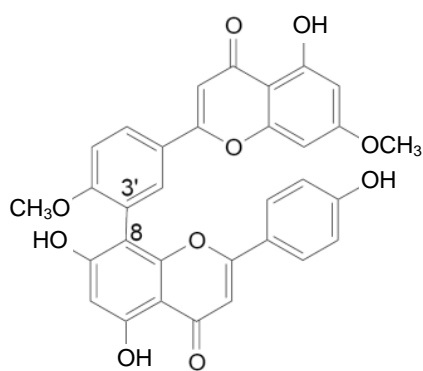

Ginkgetin<smiles>O=C1C(=O)c2c(O)cc(O)c(O)c2-c2c1oc(-c1ccc(O)cc1)cc2=O</smiles>

2',8"-biapigenin<smiles></smiles>

$\mathrm{HO}$<smiles>COc1ccc(-c2cc(=O)c3c(O)cc(OC)c(-c4cc(-c5cc(=O)c6c(O)cc(OC)cc6o5)ccc4O)c3o2)cc1</smiles>

Heveaflavone<smiles>COc1cc2oc(-c3ccc(O)cc3)cc(=O)c2c(O)c1Oc1ccc(-c2cc(=O)c3c(O)cc(O)cc3o2)cc1</smiles>

Isocryptomerin<smiles>COc1ccc(-c2cc(=O)c3c(O)cc(OC)c(-c4cc(-c5cc(=O)c6c(O)cc(O)cc6o5)ccc4O)c3o2)cc1</smiles>

Kayaflavon<smiles>O=c1cc(-c2ccc(Oc3c(O)cc4oc(-c5ccc(O)cc5)cc(=O)c4c3O)cc2)oc2cc(O)cc(O)c12</smiles>

Hinokiflavone<smiles>O=c1cc(-c2ccc(Oc3cc(-c4cc(=O)c5c(O)cc(O)cc5o4)ccc3O)cc2)oc2cc(O)cc(O)c12</smiles><smiles>COc1ccc(-c2cc(=O)c3c(O)cc(O)c(-c4cc(-c5cc(=O)c6c(O)cc(O)cc6o5)ccc4O)c3o2)cc1</smiles>

Podocarpusflavone A<smiles>O=c1cc(-c2ccc(O)c(-c3c(O)c(O)c(O)c4c(=O)cc(-c5ccc(O)cc5)oc34)c2)oc2cc(O)cc(O)c12</smiles>

Sumaflavone<smiles>O=c1cc(-c2ccc(O)c(-c3c(O)cc4oc(-c5ccc(O)cc5)cc(=O)c4c3O)c2)oc2cc(O)cc(O)c12</smiles>

Robustaflavone<smiles></smiles>

Taiwaniaflavone

Figure 2. Structure of biflavonoid from Selaginella, namely: amentoflavone, 2',8"-biapigenin, delicaflavone, ginkgetin, heveaflavone, hinokiflavone, Isocryptomerin, kayaflavone, ochnaflavone, podocarpusflavone A, robustaflavone, sumaflavone, and taiwaniaflavone. 
Delicaflavone. Its bioactivity is not observed yet from Selaginella.

Ginkgetin. This compound is the second most studied biflavonoid of Selaginella beside amentoflavone. It has several properties including antioxidant (Su et al. 2000; Sah et al. 2005; Shi et al. 2008), anti-inflammatory (Grijalva et al. 2004; Woo et al. 2005, 2006; Pokharel et al. 2006), antiviral such as herpes and cytomegalovirus (Hayashi et al. 1992); anti protozoan such as Trypanosoma cruzi (Weniger et al. 2006); anti-cancer (Sun et al. 1997; Kim and Park 2002; Yang et al. 2007), such as such as ovarian adenocarcinoma (OVCAR-3), cervical carcinoma (HeLa) and foreskin fibroblast (FS-5) (Su et al. 2000). Ginkgetin is the strongest biflavonoid that inhibits cancer (Kim and Park 2002). Besides, this matter increases activity of neuroprotective against cytotoxic stress, and has potent for curing neurodegenerative disease such as stroke and Alzheimer (Kang et al. 2004; Han et al. 2006). Ginkgetin can also replace caffeine in food-stuff and medicines without generating addiction (Zhou 2002).

Heveaflavone. Heveaflavone has cytotoxic activity against cancer cell of murine L 929 (Lin et al. 1994).

Hinokiflavone. Hinokiflavone has antioxidant, antiviral and anti protozoan effect. This matter assists cell growth and protects from free radical caused by hydrogen peroxide $\left(\mathrm{H}_{2} \mathrm{O}_{2}\right)$ (Sah et al. 2005). It also inhibits sialidase influenza virus (Yamada et al. 2007; Miki et al. 2008); has high resistance to HIV-1 by in vivo and polymerase HIV-1 RTASE by in vitro (Lin et al. 1997). Lin et al. (1998, 1999a,b, 2002) and Flavin et al. (2001, 2002) is patenting antiviral effect of hinokiflavone and others to influenza virus (A, B), hepatitis (B), human immunodeficiency virus (HIV-1), herpes (HSV-1, HSV-2), herpes zoster (VZV), and measles. It has antiprotozoan activity by in vitro against Plasmodium falciparum, Leishmania donovani and Trypanosoma sp. (Kunert et al. 2008).

Isocryptomerin. Isocryptomerin has anti-cancer property as well as anti-inflammatory, immunosuppressant and analgesic (Kang et al. 1998, 2001). It has cytotoxic activity against various cancer cells (Silva et al. 1995), including P-388 and HT-29 (Chen et al. 2005b). It has antibacterial activity against Gram-positive and Gramnegative bacteria (Lee et al. 2009b); and also has antifungal properties, which can depolarize fungal plasma membrane of Candida albicans (Lee et al. 2009a).

Kayaflavone. Kayaflavone has moderately anti-cancer property (Sun et al. 1997; Yang et al. 2007) and antioxidant, such as depleting $\mathrm{H}_{2} \mathrm{O}_{2}$ (Su et al. 2000).

Ochnaflavone. Ochnaflavone derivatives may have antioxidant activity that inhibits expression of gene COX-2 at colon cancer cell (Chen et al. 2005b).

Podocarpusflavone A. It has moderately anti-cancer (Sun et al. 1997; Yang et al. 2007) and antioxidant properties (Su et al. 2000; Shi et al. 2008).

Robustaflavone. Robustaflavone has anti-cancer and antivirus properties. This matter significantly cytotoxic to various cancer cells (Silva et al. 1995) and significantly inhibits tumor cell of Raji and Calu-1 (Lin et al. 2000), cancer cell of P-388 and HT-29 (Chen et al. 2005b). It has also antiviral properties, which indicates high resistance to polymerase HIV-1 RTASE by in vitro (Lin et al. 1997) and also influenza virus (A, B), hepatitis (B), human immunodeficiency virus (HIV-1), herpes (HSV-1, HSV-2), herpes zoster (VZV), and measles (Lin et al. 1998, 1999a,b 2002; Flavin et al. 2001, 2002).

Sumaflavone. Sumaflavone has anti-inflammatory property that able to inhibit production of NO, by mean blocking lipopolysaccharide formation that induces iNOS gene expression (Yang et al. 2006). It can also significantly inhibit ability of UV irradiation to induce matrix metalloprotease-1 and -2 (MMP-1 and -2) activities at fibroblast of primary human skin (Lee et al. 2008).

Taiwaniaflavone. It has anti-inflammatory, such as induce iNOS and COX-2 at macrophage of RAW 264.7 (Pokharel et al. 2006).

\section{MOLECULAR BIOACTIVITIES}

Selaginella is traditionally treated to cure several diseases depending on species, such as cancer or tumor (uterus, nasopharyngeal, lung, etc), wound, after childbirth, menstrual disorder, female reproduction disease, expulsion of the placenta, tonic (for after childbirth, increase body endurance, anti ageing, etc), pneumonia, respiratory infection, exhalation channel infection, inflamed lung, cough, tonsil inflammation, asthma, urethra infection, bladder infection, kidney stone, cirrhosis, hepatitis, cystisis, bone fracture, rheumatism, headache, fever, skin diseases, eczema, depurative, vertigo, toothache, backache, blood purify, blood coagulation, amenorrhea, hemorrhage (resulting menstrual/obstetrical hemorrhage, stomachic, pile or prolepses of the rectum), diarrhea, stomach-ache, sedative, gastric ulcers, gastro-intestinal disorder, rectocele, itches, ringworm, bacterial disease, bellyache, neutralize poison caused by snakebite or sprained, bruise, paralysis, fatigue, dyspepsia, spleen disease (diabetic mellitus), emmenagogue, diuretic, and to refuse black magic (Martinez 1961; Bouquet et al. 1971; Dixit and Bhatt 1974; Ahmad and Raji 1992; Bourdy and Walter 1992; Nasution 1993; Lin et al. 1994; Kambuou 1996; Caniago and Siebert 1998; Sequiera 1998; Dalimartha 1999; Mathew et al. 1999; Abu-Shamah et al. 2000; van Andel 2000; Uluk et al. 2001; Harada et al. 2002; Ma and Takahashi 2002; Warintek 2002; Winter and Jansen 2003; ARCBC 2004; Batugal et al. 2004; de Almeida-Agra and Dantas 2004; DeFilipps et al. 2004; Wijayakusuma 2004; Mamedov 2005; Khare 2007; PAM 2008; Setyawan and Darusman 2008) (Table 1). This plant has sweet taste, and gives warm effect on the body (Bensky et al. 2004).

Plants ecologically use biflavonoid to response environmental condition such as defense against pests, diseases, herbivory, and competitions; while human medically use as antioxidant, anti-inflammatory, anti cancer, anti-allergy, antimicrobial, antifungal, antibacterial, antivirus, antiprotozoal, protection to UV irradiation, vasorelaxation (vasorelaxant), heart strengthener, antihypertension, anti-blood coagulation, and influence enzyme metabolism (Havsteen 1983, 2002; Kandaswami 
and Middleton 1993, 1994; Lale et al. 1996; Bisnack et al. 2001; Duarte et al. 2001; Kromhout 2001; Kang et al. 2004; Moltke et al. 2004; Arts and Hollman 2005; Martens and Mithofer 2005; Yamaguchi et al. 2005). The antioxidant, anti-cancer and anti-inflammatory are the most important bioactivities of this secondary metabolite.

Selaginella is known to possess various molecular bioactivities depending on species, but only a few species have been detailed observe in the advanced research. Several species that also distributed in Nusantara are observed, such as $S$. tamariscina, $S$. doederleinii, $S$. involvens, $S$. moellendorffii, $S$. uncinata, and $S$. willdenowii; while the most distributed Selaginella in Nusantara namely $S$. plana has not been investigated yet (Table 2).

S. tamariscina is the most powerful and most useful plant Selaginella in the world. This herb is widely used as anticancer, antioxidant and anti-inflammatory; and also used as anti UV irradiation, anti-allergy, vasorelaxation, antidiabetic, immunosuppressant, analgesic, neuroprotectant, antibacterial, antifungal, and possess estrogenic activity. As anti cancer, $S$. tamariscina can decrease expression of MMP-2 and -9 , urokinase plasminogen activator, and inhibits growth of metastasis A549 cell and Lewis lung carcinoma (LLC) (Yang et al. 2007); inhibits proliferation of mesangial cell which activated by IL-1 $\beta$ and IL-6 (Kuo et al. 1998); inhibits leukemia cancer cell of HL-60 cell (Lee et al. 1999); induces expression of tumor suppressor gene of p53 (Lee et al. 1996); degrades leukemia cancer cell of U937 (Lee et al. 1996; Yang et al. 2007); reduces proliferation nucleus antigen cell from stomach epithelium (Lee et al. 1999); chemopreventive for gastric cancer (Lee et al. 1999); induces apoptosis of cancer cell through DNA fragmentation and nucleus clotting (Ahn et al. 2006); and induces breast cancer apoptosis through blockade of fatty acid synthesis (Lee et al. 2009c). This property is mostly given by amentoflavone and isocryptomerin (Kang et al. 1998, 2001; Lee et al. 2009c), while ginkgetin is also acted as anti-cancer to OVCAR-3 (Sun et al. 1997). As antioxidant, amentoflavone from $S$. tamariscina inhibits production of NO, which inactivates $\mathrm{NF}-\kappa \mathrm{B}$, while sumaflavone blocks lipopolysaccharide formation that induces iNOS gene expression (Yang et al. 2006). As antiinflammatory, amentoflavone, taiwaniaflavone and ginkgetin from $S$. tamariscina inhibit inflammation that induces iNOS and COX-2 at macrophage RAW 264.7 which stimulated by lipopolysaccharide (Grijalva et al. 2004; Woo et al. 2005; Pokharel et al. 2006). Amentoflavone inhibits activity of phospholipase $\mathrm{C} \gamma 1$ (Lee et al. 1996); phospholipase A-2 (PLA-2) and COX-2 (Kim et al. 1998), while 2',8"-biapigenin inhibits transactivation of iNOS gene and COX-2 through inactivate NF- $\kappa B$ and prevent translocation of p65 (Woo et al. 2006).

Amentoflavone from $S$. tamariscina inhibits fungi (Junk et al. 2006), anti-influenza and resist to HSV-1 and -2 (Rayne and Mazza 2007); hinokiflavone inhibits sialidase influenza virus (Yamada et al. 2007; Miki et al. 2008) and resists to HIV-1 (Lin et al. 1997); robustaflavone and hinokiflavone resist to polymerase HIV-1 RTASE (Lin et al. 1997); ginkgetin inhibits herpes and cytomegalovirus (Hayashi et al. 1992), by degrading protein synthesis of virus and represses gene transcription (Middleton et al. 2000). Isocryptomerin from S. tamariscina shows potent antibacterial activity against Gram-positive and Gramnegative (Lee et al. 2009b). Amentoflavone from $S$. tamariscina inhibits several pathogenic fungi (Woo et al. 2005; Jung et al. 2007). Isocryptomerin from $S$. tamariscina can depolarize fungal plasma membrane of $C$. albicans (Lee et al. 2009a).

S. tamariscina is effective ingredient to prevent and cure acute brain degenerative disease, such as stroke and dementia (Han et al. 2006). Capability to prevent brain damage is especially given by amentoflavone (Kang et al. 1998). S. tamariscina can elastic vascular smooth muscle through endothelium-related to nitric oxide (NO) activity (Yin et al. 2005). Amentoflavone from S. tamariscina induces relaxation of phenylephrine which responsible for aorta contraction (Kang et al. 2004; Yin et al. 2005). S. tamariscina containing sumaflavone and amentoflavone inhibit ability of UV irradiation to induce MMP-1 and -2 at fibroblast (Lee et al. 2008). S. tamariscina reduces histamine from peritoneal mast cell causing allergic reaction (Dai et al. 2005). S. tamariscina decreases sugar blood and lipid peroxide, and also increases insulin concentration (Miao et al. 1996). Amentoflavone from $S$. tamariscina inhibits activity of tyrosine phosphatase $1 \mathrm{~B}$ to maintain type-2 diabetic and obesity ( $\mathrm{Na}$ et al. 2007).

$S$. articulate is treated as antihemorrhagic. Water extract of this matter can moderately neutralize hemorrhagic effect and inhibits proteolysis of casein by venom (Otero et al. 2000; Winter and Jansen 2003).

S. bryopteris acts as antioxidant, anti-inflammatory, antiprotozoal, anti-UV-irradiation and antispasmodic. Water extract of $S$. bryopteris increases endurance to oxidative stress, and assists cell growth and protects from free radical stress caused by $\mathrm{H}_{2} \mathrm{O}_{2}$ (Sah et al. 2005). $S$. bryopteris is treated as anti-inflammatory and cures venereal disease (Agarwal and Singh 1999). Amentoflavone and hinokiflavone from S. bryopteris have antiprotozoal activity against $P$. falciparum, $L$. donovani and Trypanosoma sp (Kunert et al. 2008). Water extract of $S$. bryopteris also significantly reduces potent cell dying caused by UV irradiation (Sah et al. 2005), while ethanolic extract can cure stomachic (Pandey et al. 1993).

S. delicatula acts as anti-cancer and antioxidant. Water extract of $S$. delicatula has antioxidant characteristic and degrades blood cholesterol (Gayathri et al. 2005). Extract of $S$. delicatula that contained by robustaflavone and amentoflavone or its derivatives is cytotoxic against cancer cell of P-388, HT-29 (Chen et al. 2005b), Raji, Calu-1, lymphoma, and leukemia (Lin et al. 2000)

$S$. doederleinii is usually treated as anti-cancer, but also acts as antiviral and anti-inflammatory. Water extract of $S$. doederleinii has antimutagenic against both picrolonic acid- and benzo[ $\alpha]$ pyrene-induced mutation to cancer cell (Lee and Lin 1988). Ethanolic extract of S. doederleinii that is amentoflavone and heveaflavone has cytotoxic activity against cancer cell of murine L 929 (Lin et al. 1994). Extract of $S$. doederleinii also has cytotoxic against 
the three human cancer cell lines, HCT, NCI-H358, and K562 (Lee et al. 2008), and has antimutagenic effect against cholangiocarcinoma cancer, but may cause bone marrow depression (Pan et al. 2001). Amentoflavone from $S$. doederleinii has potent as antiviral and antiinflammatory agents (Lin et al. 2000). However, hordenine that isolated from $S$. doederleinii increases hypertension (Lin et al. 1991).

S. involvens has characteristics as antioxidant, antiinflammatory, and anti-bacterial. Extract of S. involvens can inhibit production and effect of free radicals of NO and expression of iNOS/IL-1 $\beta$ (Joo et al. 2007). Water extract of $S$. involvens has significantly antioxidant effect to lipid peroxides $(\mathrm{EC} 50=2 \mathrm{ug} / \mathrm{mL})$. This extract is non-toxic and degrades blood cholesterol (Gayathri et al. 2005). Water extract of $S$. involvens kills the various Leptospira strains, which causes infectious of leptospirosis diseases (Wang et al. 1963). Extract of $S$. involvens depresses activity of Propionibacterium acnes (> $100 \mathrm{ug} / \mathrm{mL}$ ), which responses to acne inflammation; although has no antibiotic property (Joo et al. 2007). Besides, water extract of $S$. involvens may have analgesic activity (ECMM 1997; Ko et al. 2007).

$S$. labordei indicates antioxidant, anticancer, and antivirus characteristics. S. labordei can inhibit activity of xanthine oxidase (XOD) and lipoxygenase (LOX), and absorb free radical (Chen et al. 2005b; Tan et al. 2009). It also down-regulate $\mathrm{COX}-2$ gene expression in human colon adenocarcinoma CaCo-2 cells (Chen et al. 2005b). Robustaflavone of $S$. labordei can inhibit hepatitis B virus (Tan et al. 2009)

S. lepidophylla has hypoglycemic property (AndradeCetto and Heinrich 2005); while non-biflavonoid compound from methanolic extract of S. lepidophylla, 3methylenhydroxy-5-methoxy-2,4-dihydroxy

tetrahydrofuran, has moderate resistance to uterus contraction (Perez et al. 1994).

$S$. moellendorffii contains antioxidant and anti-cancer properties. Ethyl acetate extract of $S$. moellendorffii contains amentoflavone, hinokiflavone, podocarpusflavone $\mathrm{A}$, and ginkgetin that has antioxidant properties (Shi et al. 2008). Ginkgetin that extracted by ethanol or ethyl acetate from S. moellendorffii can inhibit cancer cell growth of OVCAR-3, HeLa, and FS-5 (Sun et al. 1997; Su et al. 2000). It also acts as anti-metastasis at lung cancer cell of A549 and LLC (Yang et al. 2007), and apoptosis resulting caspase activation by $\mathrm{H}_{2} \mathrm{O}_{2}$ ( $\mathrm{Su}$ et al. 2000); while amentoflavone and its derivatives, kayaflavone, and podocarpusflavone A, have no this bioactivity (Sun et al. 1997).

$S$. pallescens has moderately antimicrobials and antispasmodic activities. $S$. pallescens contains an endophytic Fusarium sp. that produces pentaketide antifungal agent, CR377 (Brady and Clardy 2000). Chloroform-methanolic extract of $S$. pallescens can inhibit spontaneously contraction of ileum muscle (Rojas et al. 1999).

S. rupestris contains amentoflavone which has antispasmodic effect on ileum, and strengthening heart in case of normodynamic and hypodynamic (Chakravarthy et al. 1981)
S. sinensis contains amentoflavone which has antiviral activity against RSV (Ma et al. 2001)

S. uncinata has activity as anti-virus but generated by non biflavonoid compounds. S. uncinata has chromone glycosides, namely uncinoside A and B (Ma and Takahashi 2002), which showed antiviral activities against RSV and PIV-3 (Ma et al. 2003).

S. willdenowii contains isocryptomerin and derivatives of amentoflavone and robustaflavone which significantly cytotoxic against various cancer cell (Silva et al. 1995).

\section{TREHALOSE}

Trehalose is formed by $\alpha, \alpha-1,1$-glycosidic linkage of two low energy hexose moieties (Paiva and Panek 1996; Elbein et al 2003; Grennan 2007). This matter is a unique simple sugar which non-reactive, very stable, colorless, odor-free, non-reducing disaccharide, and capable to protect biomolecules against environmental stress (Schiraldi et al. 2002). Therefore, this compound is a natural product, although not as commonly secondary metabolites of natural products. It works as osmoprotectant during desiccation stress (Adams et al. 1990); such as compatible solute in the stabilization of biological structures under abiotic stress (Garg et al. 2002); serves as a source of energy and carbon (Elbein et al 2003; Schluepmann et al. 2003); serves as signaling molecule to control certain metabolic pathways (Muller et al. 2001; Elbein et al 2003; Avonce et al 2005); protects proteins and cellular membranes from inactivation or denaturation caused by harsh environmental stress, such as desiccation, dehydration (drought), thermal heat, cold freezing, oxidation, nutrient starvation, and salt (Avigad 1982; Elbein et al. 2003; Wu et al. 2006). Trehalose acts as a global protectant against abiotic stress (Jang et al. 2003). This matter is proved to be an active stabilizer of enzymes, proteins, biomasses, pharmaceutical preparations and even organs for transplantation (Schiraldi et al. 2002), and very prospects as molecular bio stabilizer in cosmetic, pharmacy and food (Roser 1991; Kidd and Devorak 1994). These multiple effects of trehalose on protein stability and folding suggest promising applications (Singer and Lindquist 1998).

Trehalose has long been known for protecting certain organisms from desiccation. The accumulation of the disaccharide trehalose in anhydrobiotic organisms allows them to survive severe environmental stress (Zentella et al. 1999). Trehalose also promotes survival under extreme heat conditions, by enabling proteins to retain their native conformation at elevated temperatures and suppressing the aggregation of denatured proteins (Singer and Lindquist 1998). Desiccation can reduce the lipid component in thylakoid membranes (Guschina et al. 2002). However, in desiccation-tolerant plants, membrane integrity appears not to be affected during drought-stress. S. lepidophylla retain their structural organization as intact bilayers (Platt et al. 1994) and often referred as resurrection plant because able to live on long drought and recovery through rehydration 
process (Crowe et al. 1992), even when the most water body (99\%) is evaporated (Schiraldi et al. 2002; van Dijck et al. 2002). Another species, S. tamariscina, can also remain alive in a desiccated state and resurrect when water becomes available (Liu et al. 2008). The drought can change fluorescence and pigmentation, but can not cause dying (Casper et al. 1993).

Trehalose exists in a wide variety of organisms, including bacteria, yeast, fungi, insects, invertebrates, and lower and higher plants (Elbein 1974; Crowe et al. 1984; Elbein et al. 2003), but rarely find in Angiosperms (Muller et al. 1995) and does not find in mammals (Teramoto et al 2008), and it is not accumulated to detectable levels in the most plants (Garg et al. 2002). This sugar plays important roles in cryptobiosis of Selaginella and other organisms, which revive with water from a state of suspended animation induced by desiccation (Teramoto et al 2008). Trehalose is the major sugar formed in photosynthesis of Selaginella (White and Towers 1967). Some Selaginella contains high concentration of trehalose, such as $S$. lepidophylla (Adams et al. 1990; Mueller et al. 1995; Zentella et al. 1999), S. sartorii (Iturriaga et al. 2000), S. martensii (Roberts and Tovey 1969), S. densa, and S. wallacei (White and Towers 1967). Trehalose can reach $10-15 \%$ of cell dry weight (Grba et al. 1975).

Trehalose is not merely chemical compounds that respond to resurrection ability of Selaginella. The protective effect of trehalose is correlated with trapping of the protein in a harmonic potential, even at relatively high temperature (Cordone et al. 1999). Deeba et al. (2009) suggest that $S$. bryopteris, one kind of resurrection plants, has about 250 proteins that expressed in response to dehydration and rehydration, and involved in transport, targeting and degradation in the desiccated fronds. Harten and Eickmeier (1986) suggest that several conservation enzymes are beneficial for rapid resumption of metabolic activity of S. lepidophyla. Furthermore, Eickmeier (1979; 1982) suggests that both organelle- and cytoplasm-directed protein syntheses are necessary for full photosynthetic recovery during rehydration of $S$. lepidophyla.

\section{FUTURE RESEARCH}

Research on Selaginella is still widely challenging. In the most elementary study of plant taxonomy, the high morphological variation of Selaginella causes several misidentifications of this taxon. In ecology, global warming, habitat fragmentation and degradation that affected on sustainability of this resource need to be observed. In physiology, changes of fluorescens and pigmentation caused by environmental factor and age need to be explained. In biochemistry, several natural products are not exploited yet. One of non-biflavonoid compound from Selaginella that needs to be further investigated is trehalose. Molecular study is also required clarifying certain identity and phylogenetic relationship.

In Indonesia, several authors often misidentify Selaginella species, especially on popular article. This matter is often identified as $S$. doederleinii, including Javanese wild species. The most authors agree that $S$. doederleinii is recognized as non-native plant of Indonesia, which natural distribution in India, Burma, Thailand, Laos, Cambodia, Vietnam, Malaya, Chinese, Hong Kong, Taiwan, and Japan (Huang 2006; USDA 2008). Java has no species of $S$. doederleinii according to Alston (1935a) and observation on Selaginella collection of Herbarium Bogoriense, through several Kalimantan collection is suspected and has morphological similarity to this species (ADS 2007, data is not shown). This matter is possibly caused by referring to Dalimartha (1999), which include $S$. doederleinii in Indonesian plant medicines. Harada et al. (2002) conduct similar misidentification, which cites $S$. plana as one of plant medicine in Mount Halimun NP (nowadays Mount Halimun-Salak NP), but the main picture presented is $S$. willdenowii. Field survey indicates that $S$. willdenowii is easily found in roadside to Cikaniki Research Station of Mount Halimun-Salak NP, at rice field, shrubs land, primary and secondary forest, while $S$. plana is easier to be found in country field at lower height (ADS 2008, personal observation).

Species misidentification impacts on drug properties, because each species differ chemical constituent. Natural products content of Selaginella highly varies depending on species, although does not always congruent with traditional medical recipes. Sundanese people of Mount Halimun-Salak NP complementarily or substitutionally uses several Selaginella for treatment of after childbirth including $S$. ornata, $S$. willdenowii, S. involvens, and $S$. intermedia, but for similar recipe, Sundanese around Bogor only uses S. plana (ADS 2008, personal observation). Morphological diversity at infraspecific level, and changes on pigmentation caused by age, drought and other environmental factors able to entangle identify base on morphological characteristics. It needs identification base on molecular characteristics, such as Korall et al. (1999) and Korall and Kenrick (2002, 2004). Besides, taxonomy of Malesian Selaginella needs to revise, because still based on old literature namely Alderwereld van Rosenburgh (1915a,b; 1916, 1917, 1918, 1920, 1922) and Alston (1934, 1935a,b; 1937, 1940). In a research brief about the traditional utilization of Selaginella in Indonesia, Setyawan (2009) collect at least 40 species of which half are estimated to new species or new records.

Completely research on variability of biflavonoid compounds of various Selaginella species with various solvent has not conducted yet. This matter is only conducted to certain species, compounds, and solvents. Natural products of certain plant determine economical value that required in industrial scale of modern pharmacy. Species with various low content of natural products less value than species with restricted high content, because modern pharmacy exploits natural products at molecular level. However, this matter is not always become consideration in traditional medication, because it generally uses simplicia that can be easily substituted by each other. In phytochemistry and chemotaxonomy, high variety of natural products can assist identification, though each has no high content. However, a very low compound is not 
significantly important for identification, because often influenced by environmental factors, not merely to genetic factor. Bioactivity of each biflavonoid also requires to be observed because nowadays only bioactivity of amentoflavone and ginkgetin has been completely studied. HPLC is potent method for analyzing natural products of Selaginella (Fan et al. 2007).

Besides, trehalose observation on Selaginella is still restricted on a few species, and need to be conducted to amount of other species caused by potent economic value that can be generated. It can preliminary indicated by species that in curling leaves in hot weather or drought condition.

Biflavonoid study of Selaginella is still require attention such as: (i) the importance of assuring species identity caused by height morphological variety including by using molecular method; (ii) the importance of extending research coverage most of biflavonoid type, species, and extraction method; and also (iii) the importance of extending investigation on bioactivity, including nonbiflavonoid compound, which also have high economic potent such as trehalose.

\section{CONCLUSION}

Selaginella is a potent medicinal matter, which mostly contains phenolic (flavonoid), alkaloid, and terpenoid. This matter is traditionally used to cure several diseases, especially for wound, after childbirth, and menstrual disorder. Biflavonoid, a dimeric form of flavonoids, is one of the most valuable natural products of Selaginella, which constituted at least 13 compounds, namely amentoflavone, 2',8"-biapigenin, delicaflavone, ginkgetin, heveaflavone, hinokiflavone, isocryptomerin, kayaflavone, ochnaflavone, podocarpusflavone A, robustaflavone, sumaflavone, and taiwaniaflavone. Human medically uses biflavonoid especially for antioxidant, anti-inflammatory, and anticancer. Selaginella also contains several natural products, such as trehalose which valuable for bioindustry. Selaginella research exhaustively needs to be conducted to explore all natural products constituents and their bioactivities.

\section{ACKNOWLEDGEMENTS}

I would like to thank Prof. Dr. Keon Wook Kang from Chosun University, Gwangju, South Korea which delivered a number of valuable articles on chemistry of biflavonoid. I also thank Prof. Dr. Umesh R. Desai from Commonwealth University, Virginia, USA for permitting to cite a very interesting article on biosynthesis of biflavonoid. Grateful thank to Prof. Dr. Raphael Ghogomu-Tih from University of Yaoundé, Cameron for suggesting to write this article in international language. Sincere thanks are expressed to the late Dr. Muhammad Ahkam Soebroto from Research Center for Biotechnology, Indonesian Institute of Science,
Cibinong-Bogor and anonymous peer reviewer of this article for their criticism. I also would like to thank Prof. Dr. Wasmen Manalu from SEAMEO-BIOTROP Bogor which had invited me for training in writing scientific articles.

\section{REFERENCES}

Abu-Shamah Z, Faridz ZF, Rizal MK, Fadhilah ZW, Abdullah I. 2000 Ethnobotanical study in Kuala Nerang, Kedah. In: Chang YS, Mohtar M, Bramaniam V, Abu-Samah Z (eds) Towards bridging science and herbal industry; Proceedings of the Seminar on Medicinal and Aromatic Plants. Forest Research Institute Malaysia, Kepong, Kuala Lumpur, 12-13 September 2000.

Adams RP, Kendall E, Kartha KK. 1990. Comparison of free sugars in growing and desiccated plants of Selaginella lepidophylla. Biochem Sys Ecol 18: 107-110.

Adaramoye OA, IA Medeiros. 2009. Endothelium-independent vasodilation induced by kolaviron, a biflavonoid complex from Garcinia kola seeds, in rat superior mesenteric arteries. J Smooth Muscle Res 45 (1): 39-53.

Agarwal SS, Singh VK. 1999. Immunomodulators: a review of studies on Indian medicinal plants and synthetic peptides; part 1 . medicinal plants. Pinsa 65 (3\&4): 179-204.

Ahmad F bin, Raji H. 1992. Medicinal plants of the Murut community in Sabah. In: Ghazzaly I, Siraj O, Murtedza M (eds) Forest Biology and Conservation in Borneo. Centre for Borneo Studies, Kota Kinabalu.

Ahmad I, Aqil F, Ahmad F, Owais M (ed.). 2006. Modern Phytomedicine, Turning Medicinal Plants Into Drugs. Wiley-Vch Verlag GmbH \& Co. KGaA, Weinheim.

Ahn, SH, Mun YJ, Lee SW, Kwak S, Choi MK, Baik SK, Kim YM, Woo WH. 2006. Selaginella tamariscina induces apoptosis via a caspase-3mediated mechanism in human promyelocytic leukemia cells. J Med Food 9 (2): 138-144.

Alderwereld van Rosenburgh CRWK van. 1915a. Malayan Fern Allies. Department of Agriculture, Industry and Commerce, Batavia.

Alderwereld van Rosenburgh CRWK van. 1915b. New or interesting Malay ferns 7. Bull Jard Bot Buitenzorg 2 (20): 1-28.

Alderwereld van Rosenburgh CRWK van. 1916. New or interesting Malay ferns 8. Bull Jard Bot Buitenzorg 2 (23): 1-27.

Alderwereld van Rosenburgh CRWK van. 1917. New or interesting Malay ferns 9. Bull Jard Bot Buitenzorg 2 (24): 1-8.

Alderwereld van Rosenburgh CRWK van. 1918. New or interesting Malay ferns 10. Bull Jard Bot Buitenzorg 2 (28): 1-66.

Alderwereld van Rosenburgh CRWK van. 1920. New or interesting Malay ferns 11. Bull Jard Bot Buitenzorg 3 (2): 129-186.

Alderwereld van Rosenburgh CRWK van. 1922. New or interesting Malay ferns 12. Bull Jard Bot Buitenzorg 3 (5): 179-240.

Alston AHG. 1934. The genus Selaginella in the Malay Peninsula. Gard Bull Strait Settl 8: 41-62.

Alston AHG. 1935a. The Selaginella of the Malay Islands: I. Java and the Lesser Sunda Islands. Bull Jard Bot Buitenzorg 3 (13): 432-442.

Alston AHG. 1935b. The Philippines species of Selaginella. Philip J Sci 58: 359-383.

Alston AHG. 1937. The Selaginella of the Malay Islands: II. Sumatra. Bull Jard Bot Buitenzorg 3 (14): 175-186.

Alston AHG. 1940. The Selaginella of the Malay Islands: III. Celebes and the Moluccas. Bull Jard Bot Buitenzorg 3 (16): 343-350.

Andersen ØМ, Markham KR. 2006. Flavonoids: chemistry, biochemistry, and applications. CRC Press, Taylor \& Francis Group, Boca Raton, FL.

Andrade-Cetto A, Heinrich M. 2005. Mexican plants with hypoglycaemic effect used in the treatment of diabetes. J Ethnopharmacol 99: 325348.

ARCBC [ASEAN Regional Centre for Biodiversity Conservation]. 2004. Checklist of medicinal plants in Southeast Asia. ASEAN Regional Centre for Biodiversity Conservation, Manila www.aseanbiodiversity.org/medicinal_plants/page7.htm.

Ariyasena J, Baek S-H, Perry NB, Weavers RT. 2004. Ether-linked biflavonoids from Quintinia acutifolia. J Nat Prod 67: 693-696. 
Armaka M, Papanikolaou E, Sivropoulou A (et al). 1999. Antiviral properties of isoborneol, a potent inhibitor of herpes simplex virus type 1. Antiviral Res 43: 79-92.

Arts IC, Hollman PC. 2005. Polyphenols and disease risk in epidemiologic studies. Amer J Clin Nutr 81: 317-325.

Atta-ur-Rahman, Choudhary MI. 1999. Recent studies on bioactive natural products. Pure Appl Chem 71 (6): 1079-1081

Avigad G. 1982. Sucrose and other disaccharides. In: Loewus FA, Tanner W (eds) Encyclopedia of plant physiology. Springer, New York.

Avonce N, Leyman B, Thevelein J, Iturriaga G. 2005. Trehalose metabolism and glucose sensing in plants. Biochem Soc Trans 33 (1): 276-279.

Baker W, Simmonds WHC. 1940. Derivatives of 5,6,4'- and 5,8,4'trihydroxyflavones, and a note on the structure of ginkgetin. J Chem Soc 1370-1374.

Basso, LA, da Silva LH, Fett-Neto AG, de Azevedo Jr WF, de Moreira IS, Palma MS, Calixto JB, Astolfi-Filho S, dos Santos RR, Soares MB Santos DS. 2005. The use of biodiversity as source of new chemical entities against defined molecular targets for treatment of malaria, tuberculosis, and T-cell mediated diseases; A Review. Mem Inst Oswaldo Cruz 100: 475-506.

Batugal, PA, Kanniah J, Young LS, Oliver JT (eds). 2004. Medicina plants research in Asia, Vol 1: The framework and project workplans. International Plant Genetic Resources Institute-Regional Office for Asia, the Pacific and Oceania (IPGRI-APO). Serdang, Selangor DE, Malaysia.

Baureithel KH, Buter KB, Engesser A, Burkard W, Schaffner W. 1997. Inhibition of benzodiazepine binding in vitro by amentoflavone, a constituent of various species of Hypericum. Pharm Acta Helv 72 (3): 153-157.

Bennie L, Coetzee J, Malan E, Ferreira D. 2001. Structure and stereochemistry of triflavanoids containing both ether and carboncarbon interflavanyl bonds. Phytochem 57: 1023-1034

Bennie L, Coetzee J, Malan E, Ferreira D. 2002. (4-6)-Coupled proteracacinidins and promelacacinidins from Acacia galpinii and Acacia caffra. Phytochem 60: 521-532.

Bennie L, Malan E, Coetzee J, Ferreira D. 2000. Structure and synthesis of ether-linked proteracacinidin and promelacacinidin proanthocyanidins from Acacia caffra. Phytochem 53: 785-793.

Bensky D, Clavey S, Stöger E. 2004. Chinese Herbal Medicine-Materia Medica, 3rd ed. Eastland Press, Seattle, W.A.

Berghofer R, Holzl J. 1987. Biflavonoids in Hypericum perforatum. Part 1. Isolation of I3,II8-biapigenin. Planta Med 216-217.

Berghofer R, Holzl J. 1989. Isolation of I3',II8-biapigenin (amentoflavone) from Hypericum perforatum. Planta Med 55: 91.

Bi YF, Zheng XK, Feng WS, Shi SP, Wang JF, Niu JZ. 2004b. Study on the chemical constituents of Selaginella tamariscina (Beauv.) Spring. Yao Xue Xue Bao 39 (4): 266-268.

Bi YF, Zheng XK, Feng WS, Shi SP. 2004a. Isolation and structural identification of chemical constituents from Selaginella tamariscina (Beauv.) Spring. Yao Xue Xue Bao. 39 (1): 41-45.

Bisnack R, Boersma BJ, Patel RP, Kirk M, White CR, Darley-Usmar V, Barnes S, Zhou F, Parks DA. 2001. Enhanced antioxidant activity after chlorination of quercetin by hypochlorous acid. Alcohol Clin Exp Res 25 (6): 434-443.

Bouquet A, Cave A, Paris R. 1971. Plantes medicinales du CongoBrazzaville (III) plantes medicinales et phytotherapie. Tome 5 (2): 154-158.

Bourdy G, Walter A. 1992. Maternity and medicinal plants in Vanuatu I. The cycle of reproduction. J Ethnopharmacol 37: 179-196.

Brady SF, Clardy J. 2000. CR377, a new pentaketide antifungal agent isolated from an endophytic fungus. J. Nat. Prod. 63:1447-1448

Braide VB. 1989. Antispasmodic extracts from seeds of Garcinia kola. Fitoterapia 9: 123.

Braide VB. 1993. Anti-inflammatory effect of kolaviron, a biflavonoid extract of Garcinia kola. Fitoterapia 64 (5): 433.

Caniago I, Siebert S. 1998. Medicinal plant ecology, knowledge and conservation in Kalimantan, Indonesia. Economic Botany 52 (3): 229 250 .

Casper C, Eickmeier WG, Osmond CB. 1993. Changes of fluorescence and xanthophyll pigments during dehydration in the resurrection plan Selaginella lepidophylla in low and medium light intensities. Oecol 94: 528-533.

Cassels BK, Dajas FJ, Medina JH, Paladini AC, Silveira RH. 1998 Flavonoid and biflavonoid derivatives, their pharmaceutica compositions, their anxiolytic activity. United States Patent 5756538 (May 26, 1998)

Cassels BK, Dajas FJ, Medina JH, Paladini AC, Silveira RH 1999. Flavonoid and biflavonoid derivatives, their pharmaceutical compositions, their anxiolytic activity. United States Patent 6004998 (December 21, 1999).

Chakravarthy BK, Rao YV, Gambhir SS, Gode KD. 1981. Isolation of amentoflavone from Selaginella rupestris and its pharmacological activity on central nervous system, smooth muscles and isolated frog heart preparations. Planta Med 43 (9): 64-70.

Chang CY, Chen XD, Xiao XY, Lin RC. 2000. Studies on micromorphology and its significance in anatomy and identification of Selaginella. J Med Anal 20 (2): 75-78.

Chen JJ, Duh CY, Chen JF. 2005a. New cytotoxic biflavonoids from Selaginella delicatula. Planta Med 71 (7): 659-665.

Cheng XL, Ma SC, Yu JD, Yang SY, Xiao XY, Hu JH, Lu Y, Shaw PC, But PPH, Lin RC. 2008. Selaginellin A and B, two novel natural pigments isolated from Selaginella tamariscina. Chem Pharm Bull 56 (7): 982-984.

Chikmawati T, Miftahudin. 2008. Biodiversity and potent of genus Selaginella as antioxidant and anti-cancer. LPPM IPB, Bogor.

Chikmawati T, Setyawan AD, Miftahudin. 2008. Phytochemical constituent of plant extract of Selaginella in Java. 8th Seminary and Congress of Indonesian Plant Taxonomy Association ("PTTI"), Cibinong Science Center, Bogor-Indonesia, 21-23 October 2008.

Chiu PL, Patterson GW, Salt TA. 1988. Sterol composition of pteridophytes. Phytochem 27 (3): 819-822

Cholbi MR, Paya M, Alcaraz MJ. 1991. Inhibitory effect of phenolic compounds on $\mathrm{CCl}_{4}$ induced microsomal lipid peroxidation. Experientia 47: 195-199.

Cordone L, Ferrand M, Vitrano E, Zaccai G. 1999. Harmonic behavior of trehalose-coated carbon-monoxy-myoglobin at high temperature. Biophysic J 76: 1043-1047.

Crowe JF, Hoekstra FA, Crowe LM. 1992. Anhydrobiosis. Ann Rev Physiol 54: 579-599.

Crowe JH, Crowe LM, Chapman D. 1984. Preservation of membranes in anhydrobiotic organisms: the role of trehalose. Science 223: 701-703.

Cutler SJ, Cutler HG. 2000. Biologically Active Natural Products: Pharmaceuticals. CRC Press. Boca Raton, CA.

Dai Y, But PH, Chu LM, Chan YP. 2005. Inhibitory effects of Selaginella tamariscina on immediate allergic reactions. Amer J Chin Med 33 (6): 957-966.

Dai Z, Ma SC, Wang GL, Wang F, Lin RC. 2006. A new glucoside from Selaginella sinensis. J Asian Nat Prod Res 8 (6): 529-533.

Dalimartha S. 1999. Atlas Tumbuhan Obat Indonesia. Trubus Agriwidya, Yogyakarta.

de Almeida-Agra C, Dantas IC. 2004. Identificacao dos fitoterapicos indicados pelos raizeiros e utilizados pelas mulheres no combate a enfermidades do aparelho geniturinario na cidade de Campina Grande - PB. Universidade Estadual da Paraiba, Paraiba.

Deeba F, Pandey V, Pathre U, Kanojiya S. 2009. Proteome analysis of detached fronds from a resurrection plant Selaginella bryopteris response to dehydration and rehydration. J Proteomics Bioinform 2 (2): 108-116.

DeFilipps RA, Maina SL, Crepin J. 2004. Medicinal Plants Index of the Guianas (Guyana, Surinam, French Guiana). Smithsonian Institution, Washington, D.C

Dixit RD, Bhatt GK. 1974. Ferns: A much-neglected group of medicinal plants II. J Res Indian Med 9: 59-68.

DNP [Dictionary of Natural Products]. 1992. Dictionary of Natural Products. Chapman and Hall, New York.

Duarte J, Perez-Palencia R, Vargas F, Ocete MA, Perez-Viscaio F, Zarzuelo A, Tamargo J. 2001. Antihypertensive effects of the flavonoids quercetin in spontaneously hypertensive rats. $\mathrm{Br} J$ Pharmacol 133 (1): 117-124.

Dubber MJ. 2005. Application of CE, HPLC, and LC-MS-MS for the analysis and quality control of Ginkgo biloba dosage forms. [Dissertation]. Rhodes University, Rhodes.

ECMM [Encyclopedia of Chinese Materia Medica]. 1977. Encyclopedia of Chinese materia medica (Zhongyao dacidian). Shanghai Science and Technology Press, Shanghai.

Eickmeier WG. 1979. Photosynthetic recovery in the resurrection plant Selaginella lepidophylla after wetting. Oecol 39: 93-106.

Eickmeier WG. 1982. Protein synthesis and photosynthetic recovery in the resurrection plant, Selaginella lepidophylla. Plant Physiol 69: 135138. 
Elbein AD, Pan YT, Pastuszak I, Carroll D. 2003. Review: New insights on trehalose: a multifunctional molecule. Glycobiol 13 (4). DOI: $10.1093 / \mathrm{glycob} / \mathrm{cwg} 047$.

Elbein AD. 1974. The metabolism of alpha-trehalose. Adv Carbohydr Chem Biochem 30: 227-256.

Epstein E. 1999. Silicon. Ann Rev Pl Physiol Pl Mol Biol 50: 641-664

Fan XL, Wan DR, Ye CJ, Chen KL. 2007. Study on HPLC fingerprint characteristics of Selaginella plants. Zhongguo Zhong Yao Za Zhi 32 (20):2102-2106

Farnsworth NR. 1994. Ethnobotany and the search for new drugs. John Wiley and Sons, New York.

Farombi EO, Adepoju BF, Ola-Davies OE, Emerole GO. 2005 Chemoprevention of aflatoxin B1-induced genotoxicity and hepatic oxidative damage in rats by kolaviron, a natural biflavonoid of Garcinia kola seeds. Eur J Cancer Prev 14 (3): 207-214.

Feng, WS, Chen H, Zheng XK, Wang YZ, Gao L, Li HW. 2009. Two new secolignans from Selaginella sinensis (Desv.) Spring. J Asian Nat Prod Res 11 (7): 658-662.

Ferreira D, Bekker R. 1996. Oligomeric proanthocyanidins: naturally occurring O-heterocycles. Nat Prod Rep 13: 411-433.

Ferreira D, Nel RJ, Bekker R. 1999a. In: Barton DHR, Nakanishi K, Meth-Cohn O, Pinto BM (eds) Comprehensive natural products chemistry. Elsevier, New York.

Ferreira D, Slade D, Marais JPJ. 2006. Flavans and proanthocyanidins. In: Anderson OM, Markham KR (eds) Flavonoids: chemistry, biochemistry, and applications. CRC Press, Boca Raton, FL.

Ferreira DE, Brandt V, Coetzee J, Malan E. 1999b. Condensed tannins. In: Zechmeister L, Herz W, Falk H, Kirby GW, Moore RE (eds) The chemistry of organic natural products. Springer, Wien

Flavin MT, Lin YM, Zembower DE, Schure R, Zhao GX. 2002. Biflavanoids and derivatives thereof as antiviral agents. United States Patent 6399654 (June 4, 2002).

Flavin MT, Lin YM, Zembower DE, Zhang H. 2001. Robustaflavone, intermediates and analogues and method for preparation thereof and a method for synthesizing the same are provided. United States Paten 6225481 (May 1, 2001)

Gambhir SS, Goel RK, Dasgupta G. 1987. Anti-inflammatory and antiulcerogenic activity of amentoflavone. Indian J Med Res 85: 689693.

Gao LL, Yin SL, Li ZL, Sha Y, Pei YH, Shi G, Jing YK, Hua HM. 2007. Three novel sterols isolated from Selaginella tamariscina with antiproliferative activity in leukemia cells. Planta Med 73: 1112-1115.

Garg AK, Kim JK, Owens TG, Ranwala AP, Choi YD, Kochian LV, Wu RJ. 2002. Trehalose accumulation in rice plants confers high tolerance levels to different abiotic stresses. Proc Natl Acad Sci U.S.A 99 (25): 15898-15903.

Gayathri V, Asha V, Subromaniam A. 2005. Preliminary studies on the immunomodulatory and antioxidant properties of Selaginella species. Indian J Pharmacol 37 (6): 381-385

Gil B, Sanz MJ, Terencio MC, Gunasegaran R, Paya M, Alcaraz MJ 1997. Morelloflavone, a novel biflavonoid inhibitor of human secretory phospholipase A2 with anti-inflammatory activity. Biochem Pharmacol 53: 733-740.

Grba S, Oura E, Suomalainen H. 1975. On the formation of glycogen and trehalose in baker's yeast. Eur J Appl Microbiol 2: 29-31.

Grennan AK. 2007. The role of trehalose biosynthesis in plants. Pl Physiol 144: $3-5$

Grijalva V, Navarro S, Rhule A, Shepherd DM. 2004. The immunomodulatory effects of amentoflavone on cultured macrophages (RAW264.7) and dendritic cells (DC2.4). In: Abstracts of $21^{\text {st }}$ Annual Meeting. Pacific Northwest Association of Toxicologists. Oregon, September 17-19, 2004.

Guruvayoorappan C, Kuttan G. 2007. Effect of amentoflavone on the inhibition of pulmonary metastasis induced by B16F-10 melanoma cells in C57BL/6 mice. Integr Cancer Ther 6 (2): 185-197.

Guschina IA, Harwood JL, Smith M, Beckett RP. 2002. Abscisic acid modifies the changes in lipids brought about by water stress in the moss Atrichum androgynum. New Phytol 156: 255-264.

Han BH, Kang SS, Son KH. 2006. Composition for preventing or treating acute or chronic degenerative brain diseases including extract of Selaginella tamariscina Spring. World Intellectual Property Organization Publication Number: WO/2006/001664 (January 5, 2006).

Harada K, Rahayu M, Muzakkir A. 2002. Medicinal plants of Gunung Halimun National Park, West Java, Indonesia. Biodiversity Conservation Project JICA, PHPA \& LIPI, Bogor.
Harborne JB, Baxter H, Moss GP. 1999. Phytochemical Dictionary, A Handbook of Bioactive Compounds from Plants, 2nd ed. Taylor and Francis, London.

Harborne JB, Baxter H. 1999. Handbook of natural flavonoids. John Wiley and Sons, Chichester.

Harborne JB, Williams CA. 2000. Advances in flavonoid research since 1992. Phytochem 55: 481-504.

Harborne JB. 1980. Plant phenolics. In: Bella EA, Charlwood BV (eds) Encyclopedia of plant physiology. Springer, Berlin.

Harborne JB. 1989. General Procedures and Measurement of Total Phenolics. Plant Science Laboratories, University of Reading, Whiteknights, Reading, RG6 2AS, UK.

Harten JB, Eickmeier WG. 1986. Enzyme dynamics of the resurrection plant Selaginella lepidophylla (Hook. \& Grev.) Spring during rehydration. Plant Physiol 82: 61-64.

Harvey A. 2000. Strategies for discovering drugs from previously unexplored natural products. Drug Discov Today 5 (7): 294-300.

Havsteen B. 1983. Flavonoids, a class of natural products of high pharmacological potency. Biochem Pharmacol 32 (7): 1141-1148.

Havsteen BH. 2002. The biochemistry and medical significance of the flavonoids. Pharmacol Ther 96: 67-202.

Hayashi K, Hayashi T, Morita N. 1992. Mechanism of action of the antiherpesvirus biflavone ginkgetin. Antimicrob Agents Chemother 36: 1890-1893.

Hayashi K, Hayashi T, Otsuka H (et al.) 1997. Antiviral activity of 5,6,7trimethoxyflavone and its potential of the antiherpes activity of acyclovir. J Antimicrob Chemother 39: 821-824.

Hikino H, Okuyama T, Jin H, Takemoto T. 1973. Screening of Japanese ferns for phytoecdysones. I. Chem Pharm Bull 21: 2292-2302.

Huang T-C. 2006. Flora of Taiwan. Vol. 6. 2nd ed. National University of Taiwan, Taipei

Iturriaga G, Gaff DF, Zentella R. 2000. New desiccation-tolerant plants, including a grass, in the central highlands of Mexico, accumulate trehalose. Aust J Bot 48: 153-158.

Iwu MM, Igboko OA, Okunji CO, Tempesta MS. 1990. Antidiabetic and aldose reductase activities of biflavones of Garcinia kola. J Pharm Pharmacol 42: 290-292.

Iwu MM, Igboko OA, Onwuchekwa UA, Olaniyi CO. 1987. Evaluation of the hepatotoxic activity of the biflavonoids of $G$. kola seed. J Ethnopharmacol 21 (2): 127-138.

Iwu MM, Igboko OA. 1982. Flavonoids of Garcinia kola seeds. J Nat Prod 45: 650-651.

Iwu MM. 1985. Antihepatotoxic constituents of Garcinia kola seeds. Experientia 41: 699-670.

Iwu MM. 1999. Garcinia kola: a new adaptogen with remarkable immunostimulant, anti-infective and anti-inflammatory properties. Abstract of the International Conference on Ethnomedicine and Drug Discovery; Silver Spring, Maryland, USA, November 3-5, 1999.

Jang IC, Oh SJ, Seo JS, Choi WB, Song SI, Kim CH, Kim YS, Seo HS, Choi YD, Nahm BH, Kim JK. 2003. Expression of a bifunctional fusion of the Escherichia coli genes for trehalose-6-phosphate synthase and trehalose-6-phosphate phosphatase in transgenic rice plants increases trehalose accumulation and abiotic stress tolerance without stunting growth. Pl Physiol 131: 516-524.

Jansen L. 1993. Indigenous knowledge systems in health care: A traditional medical system in Indonesia. Thesis. University of Amsterdam, The Netherland.

Joo SS, Jang SK, Kim SG, Choi JS, Hwang KW, Lee DI. 2007. Anti-acne activity of Selaginella involvens extract and its non-antibiotic antimicrobial potential on Propionibacterium acnes. Phytother Res. www3.interscience.wiley.com/cgi-bin/abstract/116328562/ ABSTRACT

Joy PP, Thomas J, Mathew S, Skaria BP. 1998. Medicinal plants. Kerala Agricultural University, Kerala.

Jung HJ, Park K, Lee IS, Kim HS, Yeo SH, Woo ER, Lee DG. 2007. SPhase accumulation of Candida albicans by anticandidal effect of amentoflavone isolated from Selaginella tamariscina. Biol Pharm Bull 30 (10): 1969-1971.

Kambuou RN. 1996. Papua New Guinea: country report. FAO International Technical Conference on Plant Genetic Resources, Leipzig, Germany, June 17-23, 1996.

Kamil M, Ilyas M, Rahman W, Hasaka N, Okigawa M, Kawano N. 1981. Taiwaniaflavone and its derivatives: a new series of biflavones from Taiwania cryptomerioides Hayata. J Chem Soc Perkin Transact 1: 553-559. 
Kandaswami C, Middleton E. 1993. The Flavonoids: Advances in Research Since 1986 (Harborne JB ed.), Chapman and Hall, London, p. 619.

Kandaswami C, Middleton E. 1994. Free radical scavenging and antioxidant activity of plant flavonoids. In: Armstrong D (ed). Free radicals in diagnostic medicine. Plenum Press. New York.

Kang DG, Yin MH, Oh H, Lee DH, Lee HS. 2004. Vasorelaxation by amentoflavone isolated from Selaginella tamariscina. Planta Med 70 (8): 718-722

Kang SS (et al) 1998. Korean Patent No. 137179 (April 25, 1998)

Kang SS (et al) 2001. Korean Patent No. 267060 (March 2, 2001)

Khare C. 2007. Indian medicinal plants - an illustrated dictionary Springer. New York.

Kidd G, Devorak J. 1994. Trehalose is a sweet target for agrobiotech. Biotechnol 12: 1328-1329.

Kim HK, Son KH, Chang HW, Kang SS, Kim HP. 1998. Amentoflavone, a plant biflavone: a new potential anti-inflammatory agent. Arch Pharmacol Res 21 (4): 406-410.

Kim J, Park EJ. 2002. Cytotoxic anticancer candidates from natura resources. Curr Med Chem Anti-Cancer Agents 2: 485-537.

Ko YJ, Park SH, Lee Y-H, Park BC, Hur JH, Min YD, Kim JK, Kim J-A 2007. Inhibitory effects of water extract of Selaginella involvens on the tube formation and invasion of human umbilical vein endothelial cells. Yakhak Hoeji 51 (1): 51-55.

Korall P, Kenrick P, Therrien JP. 1999. Phylogeny of Selaginellaceae: evaluation of generic/subgeneric relationships based on rbcL gene sequences. Intl J Plant Sci 160: 585-594.

Korall P, Kenrick P. 2002. Phylogenetic relationships in Selaginellaceae based on rbcL sequences. Amer J Bot 89: 506-517.

Korall P, Kenrick P. 2004. The phylogenetic history of Selaginellaceae based on DNA sequences from the plastid and nucleus: extreme substitution rates and rate heterogeneity. Mol Phylogenet Evol 31: $852-864$

Kraus B. 2005. Der Einfluss von Johanniskraut (Hypericum perforatum L.) - Extrakt auf immunologische Prozesse in Mikroglia-Zellkulturen [Disertation]. Technischen Universität München, Munchen.

Krauze-Baranowska M, Wiwart M. 2002, Antifungal activity of biflavones from Taxus baccata and Ginkgo biloba. Z Naturforschung 58: 65-69.

Kromhout D. 2001. Diet and cardiovascular diseases. J Nutr Health Aging 5: $144-149$

Kunert O, Swamy RC, Kaiser M, Presser A, Buzzi S, Appa-Rao AVN, Schühly W. 2008. Antiplasmodial and leishmanicidal activity of biflavonoids from Indian Selaginella bryopteris. Phytochem Lett 1 (4) 171-174.

Kuo YC, Sun CM, Tsai WJ, Ou JC, Chen WP, Lin CY. 1998. Chinese herbs as modulators of human mesangial cell proliferation: preliminary studies. J Lab Clin Med132, 76-85.

Lale A, Herbert JM, Augereau JM, Billon M, Leconte M, Gleye JJ. 1996. J Nat Prod 59: 273-276.

Lee CW, Choi HJ, Kim HS, Kim DH, Chang IS, Moon HT, Lee SY, Oh WK, Woo ER. 2008. Biflavonoids isolated from Selaginella tamariscina regulate the expression of matrix metalloproteinase in human skin fibroblasts. Bioorg Med Chem 16 (2): 732-738

Lee HS, Oh WK, Kim BY, Ahn SC, Kang DO, Shin DI, Kim J, Mheen TI, Ahn JS. 1996. Inhibition of phospholipase $\mathrm{C} \gamma 1$ activity by amentoflavone isolated from Selaginella tamariscina. Planta Med 62 (4): 293-296.

Lee IS, Nishikawa A, Furukawa F, Kasahara K, Kim SU. 1999. Effects of Selaginella tamariscina on in vitro tumor cell growth, p53 expression, G1 arrest and in vivo gastric cell proliferation. Cancer Lett 144 (1): 93-99.

Lee IS, Park SH, Rhee IJ. 1996. Molecular-based sensitivity of human leukemia cell line U937 to antineoplastic activity in a traditional medicinal plants (Selaginella tamariscina). J Fd Hyg Safety 11 (1) 71-75.

Lee J, Choi Y, Woo ER, Lee DG. 2009a. Isocryptomerin, a novel membrane-active antifungal compound from Selaginella tamariscina. Biochem Biophys Res Comm 379 (3): 676-680.

Lee J, Choi Y, Woo ER, Lee DG. 2009b. Antibacterial and synergistic activity of isocryptomerin isolated from Selaginella tamariscina. J Microbiol Biotechnol 19 (2):204-207.

Lee JS, Lee MS, Oh WK, Sul JY. 2009c. Fatty acid synthase inhibition by amentoflavone induces apoptosis and antiproliferation in human breast cancer cells. Biol Pharm Bull 32 (8): 1427-1432.
Lin LC, Kuo YC, Chou CJ. 2000. Cytotoxic biflavonoids from Selaginella delicatula. J Nat Prod 63 (5): 627-630.

Lin R, Skaltsounis AL, Seguin E, Tillequin F, Koch M. 1994. Phenolic constituents of Selaginella doederleinii. Planta Med 60 (2): 168-170.

Lin RC, Peyroux J, Seguin E, Koch M. 1991. Hypertensive effect of glycosidic derivatives of hordenine isolated from Selaginella doederleinii Hieron and structural analogues in rats. Phytotherapy Res 5 (4): 188-190.

Lin RC, Skaltsounis AL, Seguin E, Tillequin F, Koch M. 1990. The isolation and identification of a new lignanoside from Selaginella tamariscina (Beauv.) assay for anticancer-drug screening. J Natl Cancer Inst 82:

Lin YM, Anderson $\mathrm{H}$, Flavin MT, Pai YH, Mata-Greenwood E, Pengsuparp T, Pezzuto JM, Schinazi RF, Hughes SH, Chen FC. 1997. In vitro anti-HIV activity of biflavonoids isolated from Rhus succedanea and Garcinia multiflora. J Nat Prod 60: 884-888

Lin YM, Flavin MT, Schure R, Chen FC, Sidwell R, Barnard DL, Huffman JH, Kern ER. 1999a. Antiviral activities of bioflavonoids. Planta Med 65: 120-125.

Lin YM, Flavin MT, Schure R, Zembower DE, Zhao GX. 1998. Biflavanoids and derivatives thereof as antiviral agents. United States Patent 5773462 (June 30, 1998)

Lin YM, Flavin MT, Schure R, Zembower DE, Zhao GX. 1999b. Biflavanoids and derivatives thereof as antiviral agents. United States Patent 5948918 (September 7, 1999).

Lin YM, Zembower DE, Flavin MT, Schure R, Zhao GX. 2002. Biflavanoids and derivatives thereof as antiviral agents. United States Patent 6339654 B1 (June 4, 2002).

Liu MS, Chien CT, Lin TP. 2008. Constitutive components and induced gene expression are involved in the desiccation tolerance of Selaginella tamariscina. Plant Cell Physiol 49 (4): 653-663.

Lobstein-Guth A, Briancon-Scheid F, Victoire C, Haag-Berrurier M, Anton R. 1998. Isolation of amentoflavone from Ginkgo biloba. Planta Med 54: 555-556.

Locksley HD. 1973. Fortschritte der Chemie Organischer Naturstoffe 30: 207-312.

Ma JF, Takahashi E. 2002. Soil, fertilizer, and silicon research in Japan. Elsevier, Amsterdam.

Ma JF. 2004. Role of silicon in enhancing the resistance of plant to biotic and abiotic stresses. Soil Sci Pl Nutr 50: 11-18.

Ma SC, But PP, Ooi VE, He YH, Lee SH, Lee SF, Lin RC. 2001. Antiviral amentoflavone from Selaginella sinensis. Biol Pharm Bull 24 (3): 311-312.

Macheix JJ, Fleuriet A, Billot J. 1990. Fruit Phenolics. CRC Press, Boca Raton, FL.

Mamedov N. 2005. Adaptogenic, geriatric, stimulant and antidepressant plants of Russian Far East. J Cell Mol Biol 4: 71-75.

Markham KR, Gerger H, Jaggy H. 1992. Phytochemrstry 31: 009.

Martens S, Mithofer A. 2005. Flavones and flavone synthases. Phytochem 66: 2399-2407.

Martinez M. 1961. Plantas medicinales. 5th ed. Ediciones Botas. Mexico DF

Mathew PJ, Mathew D, Unnithan CM, Pushpangadan P. 1999. Ethnomedical information of some Pteridophytes of Kerala sector of Western Ghats. In: Sasikumar B, Krishnamurti B, Rema J, Ravindren PN, Peter KV (eds) Biodiversity conservation and utilization of spices, medicinal and aromatic plants. Indian Institute of Spices Research, Calicut.

Miao N, Tao H, Tong C, Xuan H, Zhang G. 1996. The Selaginella tamariscina (Beauv.) Spring complex in the treatment of experimental diabetes and its effect on blood rheology. Zhongguo Zhong Yao Za Zhi 21 (8): 493-495.

Middleton E, Kandaswami C, Theoharides TC. 2000. The effects of plant flavonoids on mammalian cells: implications for inflammation, heart disease, and cancer. Pharmacol Rev 52: 673-751.

Miki K, Nagai T, Nakamura T, Tuji M, Koyama K, Kinoshita K, Furuhata K, Yamada H, Takahashi K. 2008. Synthesis and evaluation of influenza virus sialidase inhibitory activity of hinokiflavone-sialic acid conjugates. Heterocycles 75 (4): (published online January 11, 2008).

Moltke LL von, Weemhoff JL, Bedir E, Khan IA, Harmatz JS, Goldman P, Greenblatt DJ. 2004. Inhibition of human cytochromes P450 by components of Ginkgo biloba. J Pharm Pharmacol 56: 1039-1044.

Mora A, Paya M, Rios JL, Alcaraz MJ. 1990. Structure-activity relationships of polymethoxyflavones and other flavonoids as 
inhibitors of non-enzymic lipid peroxidation. Biochem Pharmacol 40: 793-797.

Muller J, Boller T, Wiemken A. 1995. Trehalose and trehalase in plants: recent developments. Plant Sci 112: 1-9.

Muller D, Fleury JP. 1991. A new strategy for the synthesis of biflavonoids via aryl boronic acids. Tetrahedron Lett 32: 2229-2232.

Muller J, Aeschbacher RA, Wingler A, Boller T, Wiemken A. 2001. Trehalose and trehalase in Arabidopsis. Pl Physiol 125: 1086-1093.

Na M, Kim KA, Oh H, Kim BY, Oh WK, Ahn JS. 2007. Protein tyrosine phosphatase $1 \mathrm{~B}$ inhibitory activity of amentoflavone and its cellular effect on tyrosine phosphorylation of insulin receptors. Biol Pharm Bull 30 (2): 379-381.

Nahrstedt A, Butterweck V. 1997. Biologically active and other chemical constituents of the herb of Hypericum perforatum L. Pharmacopsychiatry 30: 129-134.

Nasution RE. 1993. Proceeding of the $2^{\text {nd }}$ National Seminary and Workshop on Ethnobotany. Book 1: Medicinal Plant. Yogyakarta, 2425 January 1993. Puslitbang Biologi LIPI, Fakultas Biologi UGM \& Ikatan Pustakawan Indonesia (IPI), Jakarta.

Oliveira MCC de, Carvalho MG de, da Silva CJ, Werle AA. 2002. New biflavonoid and other constituents from Luxemburgia nobilis (EICHL). J Brazilian Chem Soc 13 (1): 119-123.

Otero R, Núñez V Barona, J, Fonnegra R, Jiménez SL, Osorio RG Saldarriaga M, Díaz A. 2000. Snakebites and ethnobotany in the northwest region of Colombia. Part III: neutralization of the haemorrhagic effect of Bothrops atrox venom. J Ethnopharmacol 73 (1-2): 233-241.

Paiva CLA, Panek AD. 1996. Biotechnological applications of the disaccharide trehalose. Biotechnol Ann Rev 2: 293-314.

PAM. 2008. Pakong tulog, Selaginella tamariscina, resurrection fern herbal medicinal plants. Manila. Philippine Alternative Medicines. www.stuartxchange.com/Pakongtulog.html.

Pan KY, Lin JL, Chen JS. 2001. Severe reversible bone marrow suppression induced by Selaginella doederleinii. J Clin Toxicol 39 (6): 637-639

Pandey S, Khan AA, Shankar K, Singh N. 1993. An experimental study on the anti-stress and antioxidant activity of Selaginella bryopteris. J Biol Chem Res 12: 128-129.

Perez S, Perez RM, Perez C, Zavala MA, Vargas R. 1994. Inhibitory activity of 3-methylenhydroxy-5-methoxy-2,4-dihydroxy tetrahydrofurane isolated from Selaginella lepidophylla on smooth muscle of Wistar rat. Pharm Acta Helv 69 (3): 149-152.

Perruchon S. 2004. Synthese und struktur-aktivitäts-beziehungen von flavonoiden. [Dissertation]. Technischen Universität Darmstadt, Darmstadt.

Peter KV (ed) 2004. Handbook of Herbs and Spices. Vol 2. CRC Press, Boca Raton.

Platt KA, Oliver MJ, Thomson WW. 1994. Membranes and organelles of dehydrated Selaginella and Tortula retain their normal configuration and structural integrity; Freeze fracture evidence. Protoplasma 178 57-65.

Pokharel YR, JW Yang, JY Kim, HW Ohb, HG Jeong, ER Woo, KW Kang. 2006. Potent inhibition of the inductions of inducible nitric oxide synthase and cyclooxygenase- 2 by taiwaniaflavone. Nitric Oxide 15 (3): 217-225.

Popper ZA, Sadler IH, Fry SC. 2001. 3-O-Methyl-D-galactose residues in lycophyte primary cell walls. Phytochem 57 (5): 711-719.

Porter LJ. 1994. Flavans and proanthocyanidins. In: Harborne, JB (ed) The flavonoids, advances in research since 1986. Chapman and Hall, New York.

Rahman M, Riaz M, Desai UR. 2007. Synthesis of biologically relevant biflavanoids-A review. Chem Biodiv 4: 2495-2527.

Rayne S, Mazza G. 2007. Biological activities of extracts from sumac (Rhus spp.): a review. National Bioproducts and Bioprocesses Program, Pacific Agri-Food Research Centre, Agriculture and AgriFood Canada, Summerland BC.

Richardson PM. 1989. Flavonoids of the 'Fern Allies'. Biochem Sys Ecol 17 (2): 155-160.

Richmond KE, Sussman M. 2003. Got silicon? The non-essential beneficial plant nutrient. Curr Op Pl Biol 6: 268-272.

Robards K, Antolovich M. 1997. Analytical chemistry of fruit bioflavonoids. Analyst 122: 11R-34R

Roberts WM, Tovey KC. 1969. Trehalase activity in Selaginella martensii Arch Biochem Biophys 133: 408-412.

Rojas A, Bah M, Rojas JI, Serrano V, Pacheco S. 1999. Spasmolytic activity of some plants used by the Otomi Indians of Quéretaro
(México) for the treatment of gastrointestinal disorders. Phytomed 6 (5): 367-371.

Roser B. 1991. Trehalose a new approach to premium dry food. Trends Food Sci Technol 7: 166-169.

Sah NK, Singh SNP, Sahdev S, Banerji S, Jha V, Khan Z, Hasnain SE. 2005. Indian herb sanjeevani (Selaginella bryopteris) can promote growth and protect against heat shock and apoptotic activities of ultraviolet and oxidative stress. J Biosci 30 (4): 499-505.

Schiraldi C, Di Lernia I, De Rosa M. 2002. Trehalose production: exploiting novel approaches. Trends Biotechnol 20 (10): 420-425.

Schluepmann H, Pellny T, van Dijken A, Smeeekens S, Paul M. 2003. Trehalose 6-phosphate is indispensable for carbohydrate utilization and growth in Arabidopsis thaliana. Proc Natl Acad Sci USA 100: 6849-6854

Seigler DS. 1998. Plant Secondary Metabolism. Kluwer, Dordrecht.

Sequiera KM. 1998. Diversity, systematics, distribution, and taxonomy of epiphytic pteridophytes of Kerala part of Western Ghats, South India. Indian Fern J 15: 106-130.

Setyawan AD, Darusman LK. 2008. Review: Biflavonoid compounds of Selaginella Pal. Beauv. and its benefit. Biodiversitas 9 (1): 64-81.

Setyawan AD. 2008. Species richness and geographical distribution of Malesia Selaginella. 8th Seminary and Congress of Indonesian Plant Taxonomy Association ("PTTI"), Cibinong Science Center, BogorIndonesia, 21-23 October 2008 .

Setyawan AD. 2009. Traditionally utilization of Selaginella; field research and literature review. Nus Biosci 1: 146-155.

Shi S, Zhou H, Zhang Y, Huang K. 2008. Hyphenated HSCCC-DPPH for rapid preparative isolation and screening of antioxidants from Selaginella moellendorffii. Chromatographia 68: 173-178.

Silva GL, Chai H, Gupta MP, Farnsworth NR, Cordell GA, Pezzuto JM, Beecher CW, Kinghorn AD. 1995. Cytotoxic biflavonoids from Selaginella willdenowii. Phytochem 40 (1): 129-134.

Silva KL da, dos Santos AR, Mattos PE, Yunes RA, Delle-Monache F, Cechinel-Filho V. 2001. Chemical composition and analgesic activity of Calophyllum brasiliense leaves. Therapie 56: 431-434.

Singer MA, Lindquist S. 1998. Thermotolerance in Saccharomyces cerevisiae: the Yin and Yang of trehalose. Trends Biotechnol 16 (11): 460-468.

Smith PM. 1976. The Chemotaxonomy of Plants. Edward Arnold, London.

Soedibyo M. 1989. Philosophy of herbal medicine as the point of development of traditional medicine. Symposium on Cosmetics and Traditional Medicine II. Department of Health,, Jakarta [Indonesia]

Soedibyo M. 1990. Javanese traditional medicine. Congress on Traditional Medicine and Medicinal Plants. Denpasar, Bali, Indonesia, October 15-17, 1990 [Indonesia]

Sofowora A. 1982. Medicinal plants and traditional medicine in Africa. Spectrum Books Ltd. Ibadan, Nigeria.

Su Y, Sun CM, Chuang HH, Chang PT. 2000. Studies on the cytotoxic mechanisms of ginkgetin in a human ovarian adenocarcinoma cell line. Naunyn Schmiedebergs Arch Pharmacol 362 (1): 82-90.

Sun CM, Syu WJ, Huang YT, Chen CC, Ou JC. 1997. Selective cytotoxicity of ginkgetin from Selaginella moellendorffii. J Nat Prod 60 (4): 382-384.

Sun DM, Luo WH, Li ZY. 2006. Determination of amentoflavone in 11 species of Selaginella medicinal material by HPLC. Zhong-Yao-Cai 29 (1): 26-28.

Sutarjadi. 1990. Research and development of Indonesian jamu science. Symposium to Increasing Image and Benefit of Jamu and Traditional Drugs, and the Security to Human Body Healt. Universitas Airlangga, Surabaya.

Takemoto T, Ogawa S, Nishimoto N, Arihara S, Bue K. 1967. Insect moulting activity of crude drugs and plants (1). Yakugaku Zasshi 87: 1414-1418.

Tan WJ, Xu JC, Li L, Chen KL. 2009. Bioactive compounds of inhibiting xanthine oxidase from Selaginella labordei. Nat Prod Res 23 (4): 393-398.

Teramoto N, Sachinvala ND, Shibata M. 2008. Trehalose and trehalosebased polymers for environmentally benign, biocompatible and bioactive materials. Molecules 13 (8): 1773-816.

Tolonen A. 2003. Analysis of secondary metabolites in plant and cell culture tissue of Hypericum perforatum L. and Rhodiola rosea L. [Dissertation]. Faculty of Science, University of Oulu, Oulu.

Uluk A, Sudana M, Wollenberg E. 2001. Dependence of Dayaks society to forest around Kayan Mentarang National Park. Cifor, Bogor 
Umezawa T. 2003a. Diversity in lignan biosynthesis. Phytochem Rev 2: $371-390$

Umezawa T. 2003b. Phylogenetic distribution of lignan producing plants. Wood Res 90: 27-110.

United States Department of Agriculture (USDA). 1998. National Agricultural Statistic Service. United States Government Printing Office Washington.

van Andel TR. 2000. Non-timber forest products of the north-west district of Guyana. part I \& part II (a field guide). Tropenbos-Guyana Programme, Georgetown, Guyana.

van Dijck P, Mascorro-Gallardo JO, de Bus M, Royackers K, Iturriaga G, Thevelein JM. 2002. Truncation of Arabidopsis thaliana and Selaginella lepidophylla trehalose-6-phosphate synthase unlocks high catalytic activity and supports high trehalose levels on expression in yeast. Biochem J 366: 63-71.

Wang CC, Lu SH, Chen J, Wei H. 1963. The effect of certain wild plants and fertilizer in the killing of the genus Leptospira of orde Spirochetes. Chung-hua I-hsueh Tsa-chih 49 (6): 393-396.

Wang PS, Wang XY. 2001. Pteridophyte. In: Wang PS ed. Flora of Guizhou. Guiyang: Guizhou Science and Technology Press.

Wang YH, Long CL, Yang FM, Wang X, Sun QY, Wang HS, Sh YN, Tang GH. 2009. Pyrrolidinoindoline alkaloids from Selaginella moellendorffii. J Nat rod. 2009 May 7.

Wang YZ, Chen H, Zheng XK, Feng WS. 2007. A new sesquilignan from Selaginella sinensis (Desv.) Spring. Chin Chem Lett 18 (10): 1224 1226.

Warintek. 2002. CD-ROM mencerdaskan bangsa seri kedua http://ftp.ui.edu/bebas/v12/data/top.htm

Waterman PG, Hussain RA. 1983. Systematic significance of xanthones, benzophenones and biflavonoids in Garcinia. Biochem Sys Ecol 11: 21-30.

Weniger B, Vonthron-Senecheau C, Kaiser M, Brun R, Anton R. 2006 Comparative antiplasmodial, leishmanicidal and antitrypanosomal activities of several biflavonoids. Phytomed 13: 176-180.

White E, Towers GHN. 1967. Comparative biochemistry of the Lycopods Phytochem 6 (5): 663-667.

Wiart C. 2007. Anti-inflammatory plants. In: Ethnopharmacology of medicinal plants Asia and the Pacific. Humana Press, Berlin.

Wijayakusuma HM. 2004. To contend and to prevent lung cancer as naturally. http://cybermed.cbn.net.id

Winter WP de, Jansen PCM. 2003. Selaginella Pal. Beauv. In: Winter WP de, Amoroso VB (eds) Plant resources of south-east Asia No. 15 (2) Cryptogams: fern and fern allies. Bakhuys Publisher, Leiden.

Woo ER, Lee JY, Cho IJ, Kim SG, Kang KW. 2005. Amentoflavone inhibits the induction of nitric oxide synthase by inhibiting NF- $\kappa \mathrm{B}$ activation in macrophages. Pharmacol Res 51 (6): 539-546.

Woo ER, Pokharel YR, Yang JW, Lee SY, Kang KW. 2006. Inhibition of nuclear factor- $\kappa \mathrm{B}$ activation by 2',8"-biapigenin. Biol Pharm Bull 29 (5): 976-980

Wu W, Pang Y, Shen GA, Lu J, Lin J, Wang J, Sun X, Tang K. 2006 Molecular cloning, characterization and expression of a novel trehalose-6-phosphate synthase homologue from Ginkgo biloba. J Biochem Mol Biol 39 (2): 158-166.

Yamada H, Nagai T, Takahashi K. 2007. Anti-influenza virus compound comprising biflavonoid-sialic acid glycoside. United States Patent \& Trademark Office (USPTO) No. 20070004649 (January 4. 2007).

Yamaguchi LF, Vassao DG, Kato MJ, Mascio P. 2005. Biflavonoids from Brazilian pine Araucaria angustifolia as potentials protective agents against DNA damage and lipoperoxidation. Phytochem 66: 22382247

Yang JW, Pokharel YR, Kim MR, Woo ER, Choi HK, Kang KW. 2006. Inhibition of inducible nitric oxide synthase by sumaflavone isolated from Selaginella tamariscina. J Ethnopharmacol 105 (1-2): 107-113.

Yang SF, Chu SC, Liu SJ, Chen YC, Chang YZ, Hsieh YS, 2007. Antimetastatic activities of Selaginella tamariscina (Beauv.) on lung cancer cells in vitro and in vivo. J Ethnopharmacol 110 (3): 483-489.

Yen KY, Yang LL, Okuyama T, Hikino H, Takemoto T. 1974. Screening of Formosan ferns for phytoecdysones. Chem Pharm Bull 22: 805808.

Yin MH, Kang DG, Choi DH, Kwon TO, Lee HS. 2005. Screening of vasorelaxant activity of some medicinal plants used in Oriental medicines. J Ethnopharmacol 99 (1): 113-117.

Yuan Y, Wang B, Chen L, Luo H, Fisher D, Sutherland IA, Wei Y. 2008. How to realize the linear scale-up process for rapid purification using high-performance counter-current chromatography. J Chromatogr A 1194 (2): 192-198.

Zentella R, Mascorro-Gallardo JO, van Dijck P, Folch-Mallol J, Bonini B, van Vaeck C, Gaxiola R, Covarrubias AA, Nieto-Sotelo J, Thevelein JM, Iturriaga G. 1999. A Selaginella lepidophylla trehalose-6phosphate synthase complements growth and stress-tolerance defects in a yeast tps 1 mutant. Pl Physiol 119: 1473-1482.

Zhang LP, Liang YM, Wei XC, Cheng DL. 2007. A new unusual natural pigment from Selaginella sinensis and its noticeable physicochemical properties. J Org Chem 72: 3921-3924.

Zheng JX, Wang NL, Gao H, Liu HW, Chen HF, Fan M, Yao XS. 2008a. A new flavonoid with a benzoic acid substituent from Selaginella uncinata. Chin Chem Lett 19 (9): 1093-1095.

Zheng X, Du J, Xu Y, Zhu B, Liao D. 2007. A new steroid from Selaginella pulvinata. Fitoterapia 78 (7-8): 598-599.

Zheng XK, Li KK, Wang YZ, Feng WS. 2008b. A new dihydrobenzofuran lignanoside fro om Selaginella moellendorffii Hieron. Chin Chem Lett 19 (1): 79-81.

Zheng XK, Shi SP, Bi YF, Feng WF, Wang JF, Niu JZ. 2004. The isolation and identification of a new lignanoside from Selaginella tamariscina (Beauv.) Spring. Yao Xue Xue Bao 39 (9): 719-721.

Zhou JH. 2002. Herbal caffeine replacement composition and food products incorporating same. United States Patent 6416806 (July 9, 2002).

Zhu TM, Chen KL, Zhou WB. 2008. A new flavone glycoside from Selaginella moellendorffii Hieron. Chin Chem Lett 19 (12): 14561458 . 